\title{
Probing multivalent carbohydrate-lectin interactions by an enzyme-linked lectin assay employing covalently immobilized carbohydrates
}

\author{
Caroline Maierhofer, Katja Rohmer and Valentin Wittmann* \\ Universität Konstanz, Fachbereich Chemie, Fach M 709, 78457 Konstanz, Germany
}

Received 5 June 2007; revised 27 August 2007; accepted 31 August 2007

Available online 6 September 2007

\begin{abstract}
We report here the synthesis of a series of mono- to trivalent $N$-acetylglucosamine (GlcNAc) derivatives as ligands for the plant lectin wheat germ agglutinin (WGA). Their WGA binding potencies were determined by an established enzyme-linked lectin assay (ELLA) employing microtiter plates with non-covalently immobilized porcine stomach mucin (PSM) as reference ligand and an ELLA with a new GlcNAc derivative covalently immobilized via a thiourea linkage. Comparison of both assays revealed that the type of presentation of GlcNAc residues on the microtiter plates either as part of a glycoprotein or as a covalently immobilized monosaccharide derivative strongly influences the outcome of the assay. Although the apparent dissociation constants $K_{\mathrm{D}}^{\mathrm{ELLA}}$ for the interaction of peroxidase-labeled WGA with the microtiter plates are comparable for both surfaces, $\mathrm{IC}_{50}$ values obtained with the PSM-free ELLA were substantially lower. Even more strikingly, this ELLA displayed a better differentiation between ligands of different valency leading to significantly higher relative inhibitory potencies of multivalent ligands compared to monovalent. Additionally, problems associated with the use of PSM, such as maximum inhibition at considerably less than $100 \%$ and poor reproducibility of $\mathrm{IC}_{50}$ values could be overcome with this type of ELLA.
\end{abstract}

(c) 2007 Elsevier Ltd. All rights reserved.

\section{Introduction}

The specific recognition of carbohydrate structures in biological systems by carbohydrate-binding proteins (lectins) $)^{1-4}$ is the basis of numerous intra- and intercellular events ranging from the control of protein folding to cell-cell communication during development, inflammation, immune responses, and cancer metastasis. ${ }^{5-9}$ High affinity lectin ligands are of great medicinal interest in the diagnosis and inhibition of such carbohydrate-mediated processes. ${ }^{10-15}$ The generation of high affinity ligands, however, is not trivial because the interaction of individual carbohydrate epitopes with lectins is in many cases weak and undiscriminating. ${ }^{16}$ The binding affinity can be dramatically increased by clustering of lectin binding sites and carbohydrate recognition units. ${ }^{17-23}$ The observation that the binding affinity increases exponentially with the number of binding sites has been termed the glycoside cluster effect. ${ }^{24,25}$ The po-

\footnotetext{
$\overline{\text { Keywords: }}$ Carbohydrates; Lectins; Multivalency; Assay; Immobilization.

* Corresponding author. Tel.: +49 753188 4572; fax: +49 753188 4573; e-mail: mail@valentin-wittmann.de
}

tency of a polyvalent inhibitor depends on the spatial presentation of the carbohydrates and the associated possibility of occupying several binding sites simultaneously ${ }^{26}$ and is often assessed in terms of a relative inhibitory potency compared to the monovalent interaction. If the 3D structure of a lectin is known, suitable multivalent ligands may be obtained by rational design. ${ }^{27,28}$ However, if the three-dimensional orientation of the binding sites of a lectin is not known, many potential ligands have to be synthesized and screened to determine the required orientation of the carbohydrate units.

Enzyme-linked lectin assays (ELLA) ${ }^{29}$ provide a fast method to evaluate lectin binding properties of soluble natural or synthetic lectin ligands in solution. ${ }^{30-34}$ Microtiter plates are coated with a reference ligand (often a (neo)glycoprotein or polysaccharide) and $\mathrm{IC}_{50}$ values for inhibition of the binding of an enzyme-labeled lectin to the immobilized reference ligand (the matrix) by the soluble ligands to be tested are determined. The advantage of ELLA compared to solid-phase binding assays such as surface plasmon resonance (SPR) ${ }^{35}$ is that both, lectin and ligand are in solution. However, the use of glycoproteins from natural sources as reference ligands is limited because their varying complex 
carbohydrate composition due to microheterogeneity ${ }^{36}$ leads to reduced reproducibility of $\mathrm{IC}_{50}$ values. Furthermore, incomplete inhibition of lectin binding to the plate surface is often observed, that is, maximal inhibition occurs at considerably less than $100 \%$. To overcome the problem of microheterogeneity, covalent immobilization of defined synthetic carbohydrates and their application in an enzyme-linked immunosorbent assay (ELISA) employing PapG adhesin was reported. ${ }^{37}$

From screening of a 19440-membered split-and-mix library of conformationally restricted spatially diverse glycoclusters, we were able to identify a number of tetrato hexavalent ligands of the plant lectin wheat germ agglutinin (WGA) with affinities up to 620-fold compared to the binding of the monovalent ligand $\mathrm{N}$-acetylglucosamine (GlcNAc). ${ }^{38}$ WGA is a $36-\mathrm{kDa}$ lectin composed of two identical glycine- and cysteine-rich subunits. ${ }^{39}$ The WGA dimer contains a total of eight binding sites for GlcNAc and oligomers thereof. ${ }^{40}$ The results demonstrated that the binding affinity of the identified ligands was not only determined by the number of GlcNAc residues but that ligand architecture is important as well.

Here we present a series of structurally diverse mono- to trivalent GlcNAc derivatives which were synthesized to explore the effects of scaffold structure on the binding affinity toward WGA. IC $_{50}$ values were determined by a published ELLA ${ }^{38,41}$ and an ELLA employing a newly developed GlcNAc derivative which was covalently immobilized to microtiter plates via a thiourea linkage leading to improved properties regarding sensitivity and reproducibility. Comparison of both assays revealed interesting insight into the influence of the type of carbohydrate presentation on the microtiter plates on the results of the assay.

\section{Results and discussion}

\subsection{Synthesis of WGA ligands}

In a previous study we identified several cyclic neoglycopeptides containing four to six GlcNAc residues as ligands for WGA. $^{38}$ Interestingly, a pentavalent compound showed a lower $\mathrm{IC}_{50}$ value than a hexavalent, as determined by an ELLA. This indicated that the binding affinity is not only determined by the number of GlcNAc residues but that their spatial presentation is important as well. In order to further investigate the effects of the structure of multivalent GlcNAc derivatives on the binding affinity toward WGA, a series of compounds were prepared. Commercially available amines 1-8 (Fig. 1) were reacted with activated carbonate 9 , which was already used for the preparation of neoglycopeptides, ${ }^{42}$ leading to mono- to trivalent glycoconjugates 10-17 in high yields (Table 1). Subsequent Odeacetylation resulted in WGA ligands 18-25 in quantitative yields (Scheme 1). When reacted under Zemplén conditions followed by neutralization using acidic ion exchange resin, some of the products (especially the amines 24 and 25) adhered to the resin. Therefore,

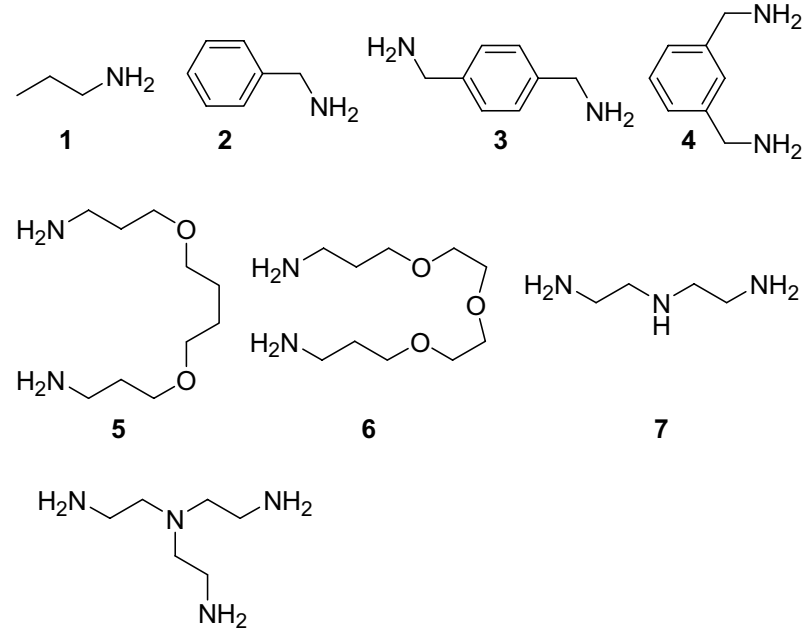

8

Figure 1. Amines used for the synthesis of WGA ligands.

Table 1. Coupling of activated carbonate 9 to amines $\mathbf{1}-\mathbf{8}^{\mathrm{a}}$

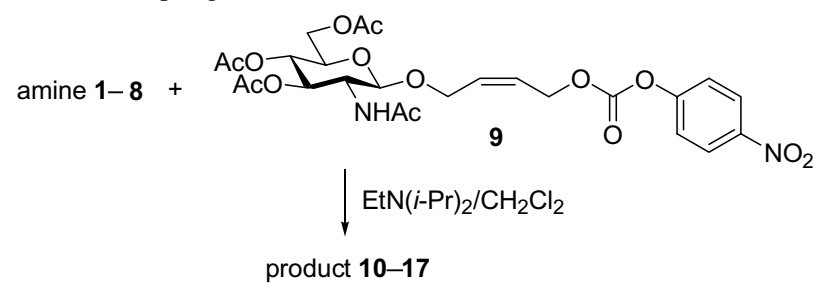

\begin{tabular}{lll}
\hline Amine & Product & Yield (\%) \\
\hline $\mathbf{1}$ & $\mathbf{1 0}$ & 85 \\
$\mathbf{2}$ & $\mathbf{1 1}$ & 94 \\
$\mathbf{3}$ & $\mathbf{1 2}$ & 97 \\
$\mathbf{4}$ & $\mathbf{1 3}$ & 96 \\
$\mathbf{5}$ & $\mathbf{1 4}$ & 83 \\
$\mathbf{6}$ & $\mathbf{1 5}$ & 92 \\
$\mathbf{7}$ & $\mathbf{1 6}$ & 94 \\
$\mathbf{8}$ & $\mathbf{1 7}$ & 99 \\
\hline
\end{tabular}

${ }^{\mathrm{a}}$ For structures of products, see Scheme 1 .

O-deacetylation was conveniently carried out under salt free conditions using $N$-ethyldimethylamine in methanol.

In addition, hydroxybutenyl glycoside 27 , obtained by O-deacetylation of compound $\mathbf{2 6},{ }^{43}$ GlcNAc 28, and allyl 2-acetamido-2-deoxy- $\beta$-D-glucopyranoside 29 were used as monovalent WGA ligands (Scheme 2).

\subsection{ELLA employing non-covalently immobilized porcine stomach mucin as reference ligand}

Binding potencies of compounds 18-25 and 27-29 were determined by an ELLA employing non-covalently immobilized porcine stomach mucin (PSM) as reference ligand as described earlier. ${ }^{38,41}$ PSM-coated microtiter plates were incubated with mixtures of horseradish peroxidase (HRP)-labeled WGA $\left(1 \mu \mathrm{g} \mathrm{mL}^{-1}\right)$ and synthetic WGA ligands in varying concentrations. It is worth mentioning that precipitate formation during incubation 

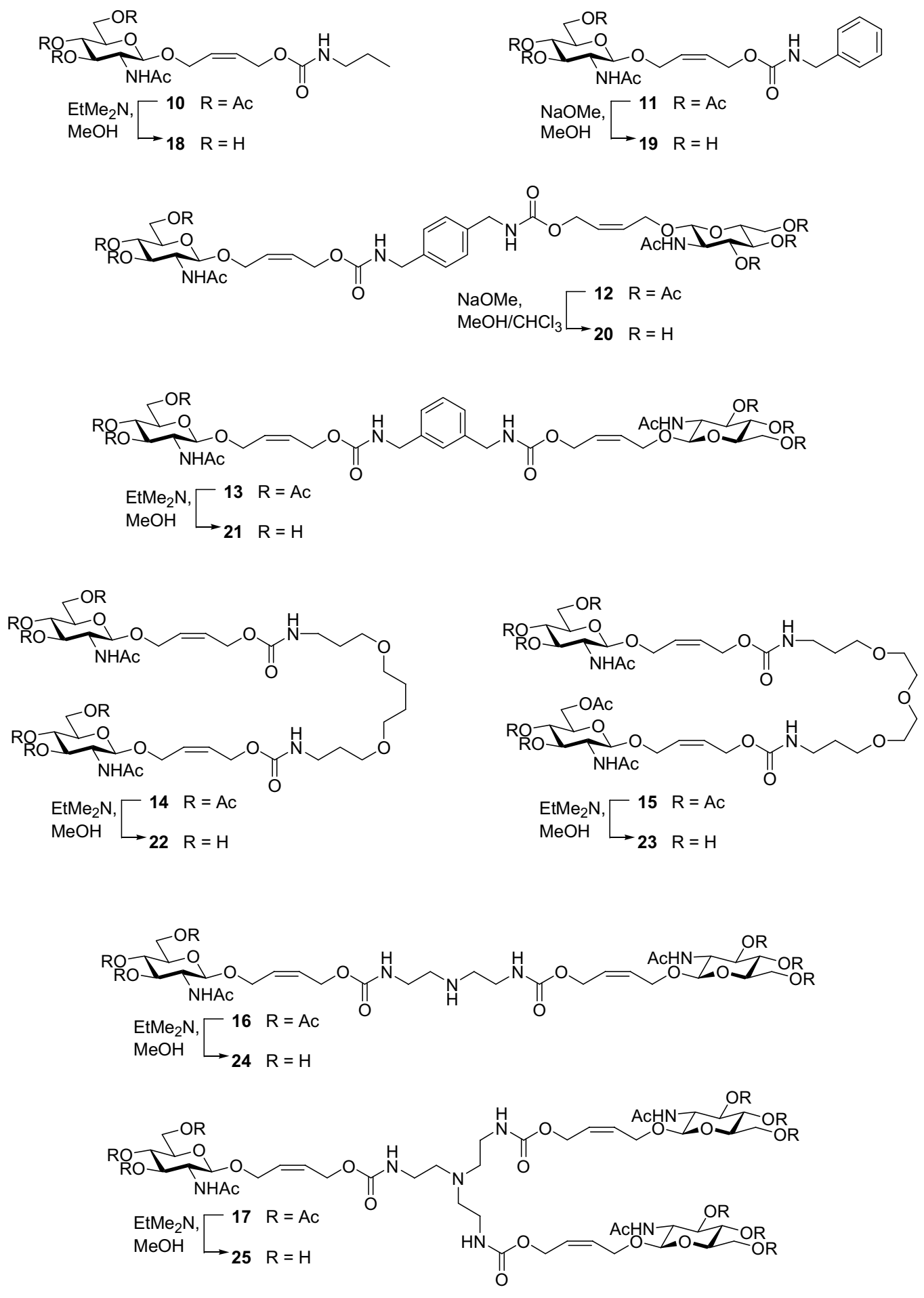

Scheme 1. Deacetylation of glycoconjugates 10-17.

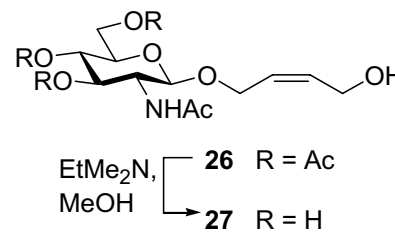

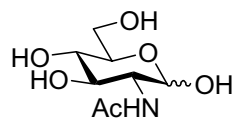

28

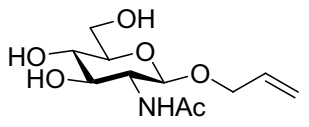

29

Scheme 2. Additional monovalent WGA ligands 27-29. 
under the given experimental conditions was not observed. After incubation, the plates were washed and remaining labeled WGA bound to the reference ligand was quantified by a HRP-catalyzed color reaction using 2,2'-azinobis(3-ethylbenzothiazoline-6-sulfonic acid) diammonium salt (ABTS) as substrate. Dose-response curves for inhibition of the binding of HRP-labeled WGA to immobilized PSM are shown in Figure 2. From these curves the concentrations that reduce the binding of labeled WGA to PSM by $50 \%$ ( $\mathrm{IC}_{50}$ values) were determined as a measure of potency of the synthesized inhibitors (Table 2, column A). Also shown in Table 2 are relative inhibitory potencies ( $\beta$ values) referenced to GlcNAc $28(\beta=1)$.

As shown in Table 2, column $\mathrm{A}$, the $\mathrm{IC}_{50}$ value of GlcNAc 28 was determined to be $1000 \mathrm{mM}$. In order to val- idate the assay, we determined the inhibitory potency of allyl 2-acetamido-2-deoxy- $\alpha$-D-glucopyranoside at a concentration of $15 \mathrm{mM}$ to be $12 \%$ (data not shown). This corresponds well to the value of $15 \%$ published by Zanini and Roy. ${ }^{41}$ The monovalent ligands 18, 27, and 29 are all slightly better inhibitors than GlcNAc 28 with a maximum $\beta$ value of 4.2 for compound $\mathbf{1 8}$. As expected, a further increase of the inhibitory potency is observed for the multivalent ligands $\mathbf{2 0}-\mathbf{2 5}$. The $\beta$ values of divalent derivatives 22-24 are in a range of 13-25 and that of trivalent ligand $\mathbf{2 5}$ is $\mathbf{4 0}$. Remarkably, the best inhibitors are the divalent compounds $\mathbf{2 1}$ and $\mathbf{2 0}$ ( $\beta=50$ and 67, respectively). On the first view, this might indicate the influence of the aromatic spacer giving 20 and 21 a lower flexibility than 22-24. However, a closer examination of the inhibition curves obtained from these ligands containing aromatic spacers reveals
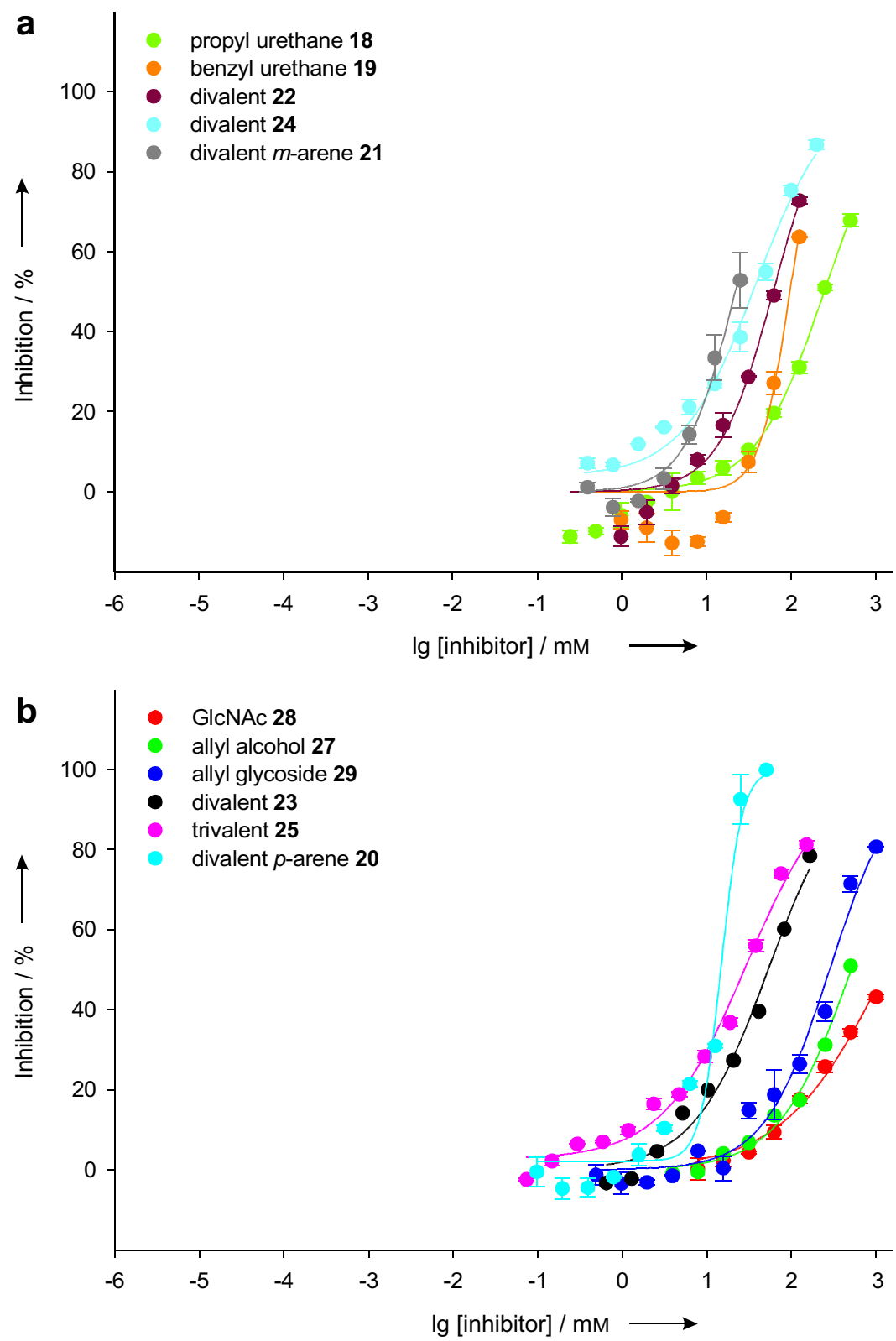

Figure 2. Dose-response curves for inhibition of the binding of HRP-labeled WGA to PSM-coated microtiter plates by (a) synthetic ligands 18, 19, 21, 22, and 24, (b) 20, 23, 25, and 27-29. 
Table 2. Absolute and relative $\mathrm{IC}_{50}$ values of synthetic ligands 18-25 and 27-29 for inhibition of the binding of HRP-labeled WGA to (A) noncovalently immobilized porcine stomach mucin (PSM) from dose-response curves shown in Figure 2 and (B) covalently immobilized GlcNAc $\mathbf{3 4}$ from dose-response curves shown in Figure 4

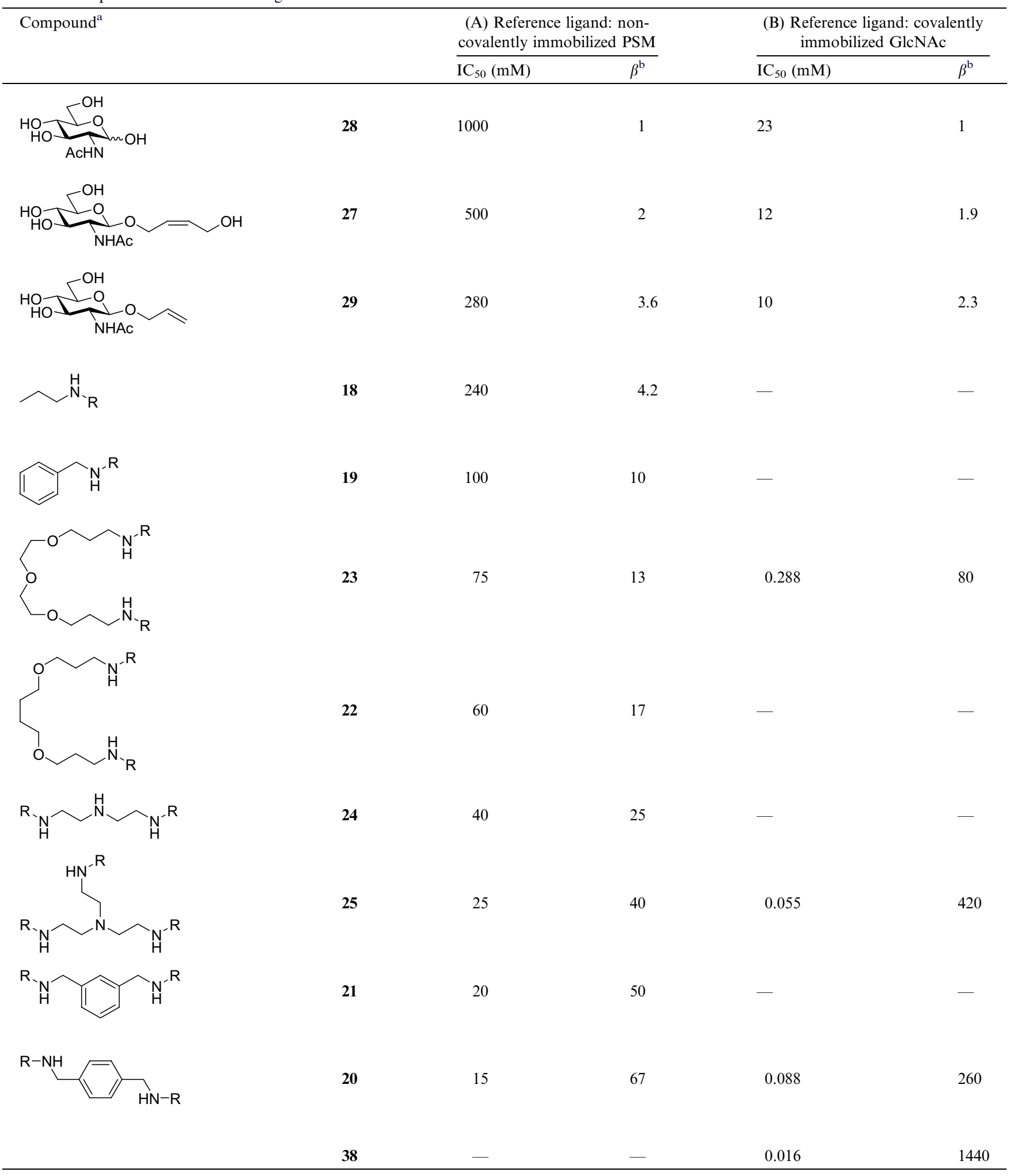

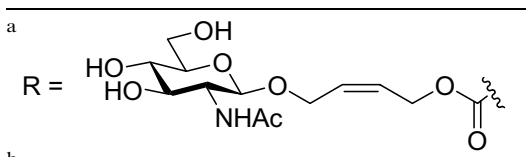

${ }^{\mathrm{b}} \beta=$ relative inhibitory potency. 
that they are exceptionally steep. One possible explanation for this behavior is increasing aggregation of the ligands at higher concentrations, leading to higher valency and, therefore, better inhibition. In this regard, it is conspicuous that the inhibition curve of monovalent derivative 19 containing benzyl groups also displays this behavior.

As shown in Figure 2, the inhibitor concentrations needed for the maximal inhibition of the binding of HRP-labeled WGA to immobilized PSM could not be reached in most cases due to insufficient solubility of the ligands. In addition, we experienced that the reproducibility of the assay is limited when the experimental setup is changed, for example, differences in $\mathrm{IC}_{50}$ values up to one order of magnitude were observed with different sources of PSM and microtiter plates. The order of inhibitory potencies of different ligands, however, is generally robust to these variables. The disadvantages associated with PSM prompted us to develop a new ELLA employing a surface covalently modified with a defined GlcNAc derivative, thus avoiding the use of PSM.

\subsection{Enzyme-linked lectin assay employing covalently immobilized GlcNAc as reference ligand}

2.3.1. Modification of amino functionalized microtiter plates. Covalent immobilization of carbohydrates has recently gained immense interest for the preparation of carbohydrate microarrays and several methods for the site-specific, covalent attachment of chemically modified carbohydrates to appropriately derivatized surfaces have been published. The field has been extensively reviewed. ${ }^{44-49}$ We compared two methods for chemical immobilization of GlcNAc leading to constructs with different spacing between the carbohydrate and the surface (Scheme 3). Commercially available amino modified microtiter plates $\mathbf{3 0}$ were treated with activated carbonate 9 in the presence of Hünig's base. O-Deacetylation under Zemplén conditions gave GlcNAc-modified microtiter plates 31 containing a short spacer. Alternatively, microtiter plates $\mathbf{3 0}$ were reacted with 1,4-phenylene diisothiocyanate according to a modified procedure originally described by Guo et al. for the fabrication of DNA microarrays ${ }^{50}$ to generate amine-reactive isothiocyanate surface 32. Addition of the amino spacer modified GlcNAc derivative $\mathbf{3 3}$ gave GlcNAc surface 34 with a longer spacer.

For the synthesis of 33, activated carbonate 9 was reacted with mono tritylated diamine $\mathbf{3 5}$ to give urethane 36 in quantitative yield (Scheme 4). Detritylation using trifluoroacetic acid (TFA) and triisopropyl silane (TIS) and subsequent $\mathrm{O}$-deacetylation of $\mathbf{3 7}$ yielded $\mathbf{3 3}$.

To determine the performance of the surfaces $\mathbf{3 1}$ and $\mathbf{3 4}$, microtiter plates prepared under various conditions were blocked with bovine serum albumin (BSA) and incubated with a series of differently concentrated WGA-HRP solutions. After washing, HRP substrate ABTS was added and the absorption was measured at $405 \mathrm{~nm}$ (Fig. 3). This allowed quantification of HRP-labeled lectin bound to the plates. To generate surface 31, the concentration of activated carbonate 9 was varied between 0.06 and $100 \mathrm{mM}$. Incubation with WGAHRP occurred at concentrations between 0.2 and $25 \mu \mathrm{g} \mathrm{mL}^{-1}$. As shown in Figure 3a, the amount of bound WGA-HRP is very low $\left(A_{405}\right.$ generally below

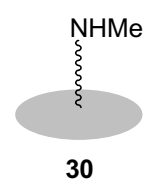

1. 9, $\operatorname{EtN}(i-\operatorname{Pr})_{2}, \mathrm{DMSO}$ 2. $\mathrm{NaOMe}, \mathrm{MeOH}$
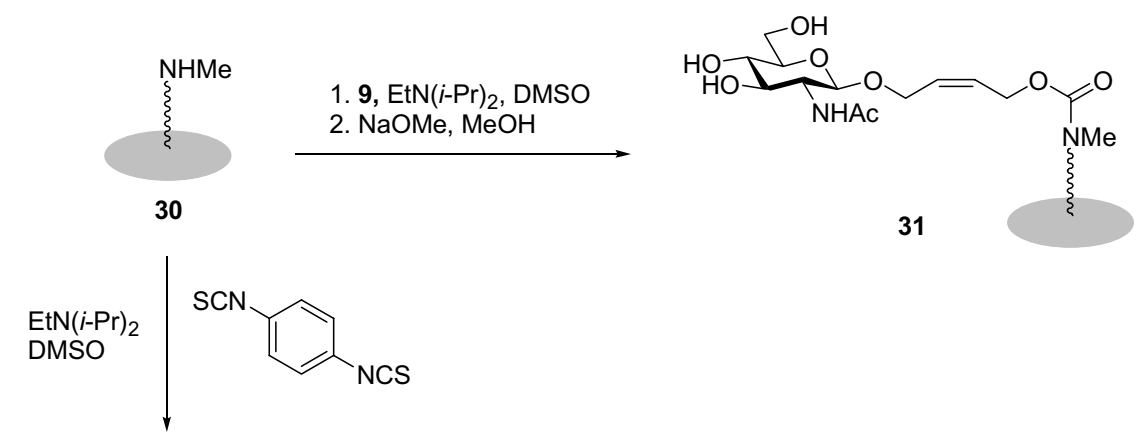

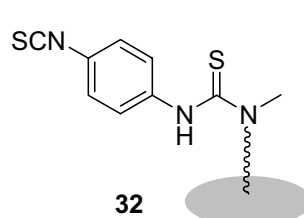

32

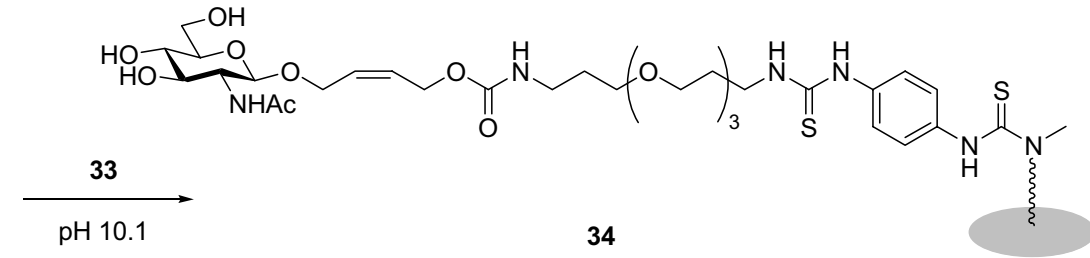

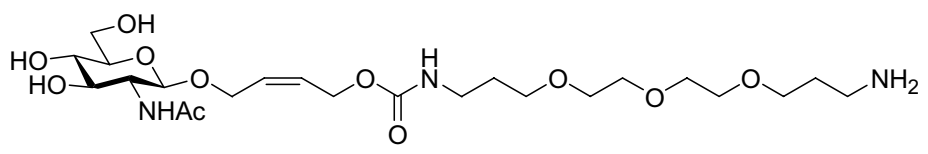



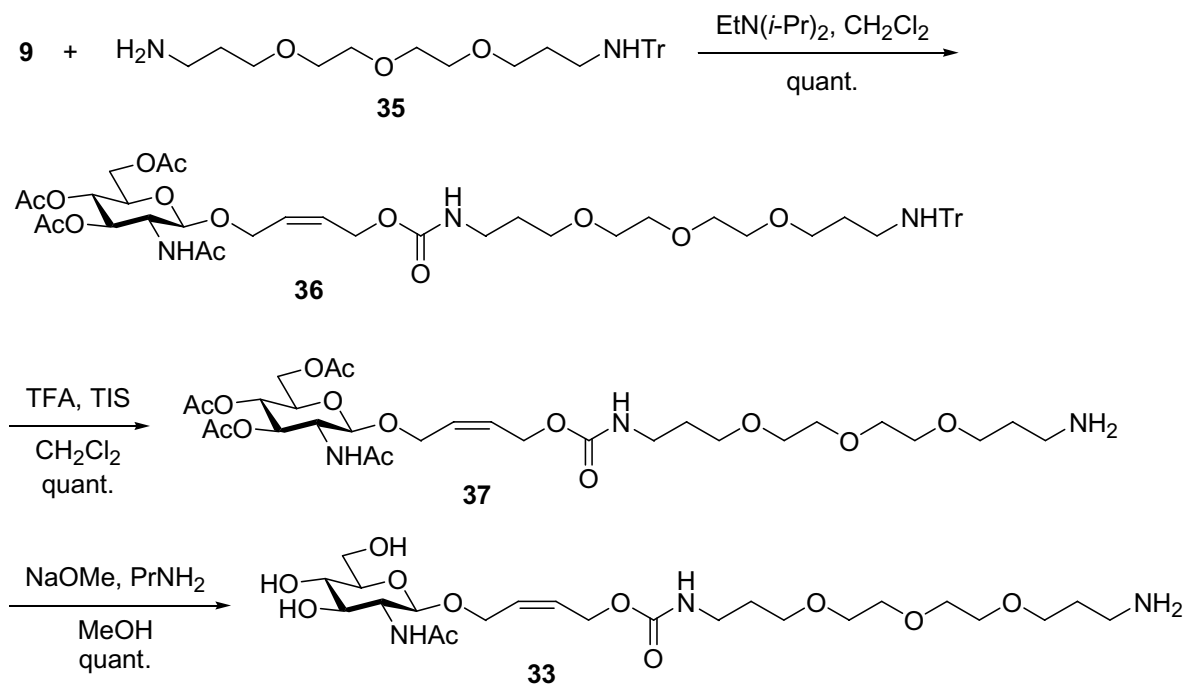

Scheme 4. Synthesis of spacer-modified GlcNAc 33.

0.5 ) and does not correlate with the concentration of activated carbonate 9 used for surface preparation. From these results we conclude that the observed binding of WGA-HRP is not a matter of a specific interaction with the immobilized GlcNAc residues. This may originate from the short distance between the plate surface and the GlcNAc residues reducing the accessibility of the GlcNAc residues to the WGA binding sites. ${ }^{51}$

A completely different behavior was observed with longspacer surface 34. A clear relationship between the concentration of $\mathbf{3 3}$ used for derivatization of $\mathbf{3 2}$ and the amount of WGA-HRP bound to the surface is observed (Fig. 3b). At concentrations of amine $33 \geqslant 1 \mathrm{mM}$, the reactive surface of the plate is saturated and binding curves consistent with simple ligand binding are obtained with increasing WGA-HRP concentration. Additionally, the total amount of WGA-HRP bound to surface 34 is much higher compared to $\mathbf{3 1}$. Therefore, all following experiments were carried out with microtiter plates $\mathbf{3 4}$ obtained by treatment of $\mathbf{3 2}$ with $1 \mathrm{mM}$ solutions of GlcNAc derivative 33.

2.3.2. Determination of inhibitory potencies. Inhibition experiments with ligands $\mathbf{2 7 - 2 9 , 2 0 , 2 3}$, and $\mathbf{2 5}$ were carried out as described above for PSM-coated microtiter plates at WGA-HRP concentrations of $1 \mu \mathrm{g} \mathrm{mL}^{-1}$. Dose-response curves for inhibition of the binding of HRP-labeled WGA to covalently immobilized GlcNAc 34 are shown in Figure 4 . $\mathrm{IC}_{50}$ values obtained from these curves are given in Table 2, column B.

As can be seen immediately, $\mathrm{IC}_{50}$ values obtained with covalently modified microtiter plates were substantially lower than those obtained with PSM-coated plates. The $\mathrm{IC}_{50}$ value of GlcNAc 28 is $23 \mathrm{mM}$ instead of $1000 \mathrm{mM}$. Similarly, inhibitory potencies of the other monovalent compounds investigated are lowered by a comparable factor of roughly 30-40, leading not only to the same order of potencies but also to similar relative inhibitory potencies ( $\beta$ values). The $\mathrm{IC}_{50}$ values of di- and trivalent ligands $\mathbf{2 3}$ and $\mathbf{2 5}$ on the other hand are lowered by a much higher factor, resulting in $\beta$ values of 80 and 420 versus 13 and 40, respectively. The inhibition curve of dimer $\mathbf{2 0}$ with the aromatic spacer is not any more as steep as in Figure $2 \mathrm{~b}$. The $\mathrm{IC}_{50}$ value of $\mathbf{2 0}$ is still lower than that of divalent $\mathbf{2 3}$ but is now higher than the $\mathrm{IC}_{50}$ of trivalent 25 . If aggregation caused the steep increase of the curves shown in Figure $2 b$, it is obviously not any more effective at the low concentration needed for inhibition of WGA binding to the covalently modified plates. Additionally, due to the lower $\mathrm{IC}_{50}$ values observed with this variant of the ELLA, limited solubility did not any more prevent reaching maximal inhibition with all tested ligands.

It is well known that the performance of multivalent carbohydrate ligands is strongly dependent on the assay used to evaluate them because different phenomena may be measured. This does not only apply to absolute $\mathrm{IC}_{50}$ values but also to observed multivalency effects, that is, relative $\mathrm{IC}_{50}$ values. Toone et al., for example, compared a range of competitive and non-competitive binding assays, including ELLA, hemagglutination inhibition, and isothermal titration microcalorimetry ${ }^{32}$ and Pieters et al. studied multivalent galectin ligands by a solid-phase inhibition assay and fluorescence titrations in solution. ${ }^{52}$ There are also few reports that show that the use of ELLA with different matrices can lead to different relative inhibitory potencies. ${ }^{33,53}$ This phenomenon, however, is not well understood.

A likely explanation for different absolute $\mathrm{IC}_{50}$ values found with different matrices could be that the lectins to be investigated have different binding affinities to the immobilized reference ligands and, therefore, varying concentrations of inhibitors are necessary for inhibition of this interaction. To investigate whether this explanation could count for the lower $\mathrm{IC}_{50}$ values obtained with our PSM-free ELLA, we compared the affinities of WGA-HRP binding to PSM-coated microtiter plates on one hand and covalently modified plates $\mathbf{3 4}$ 

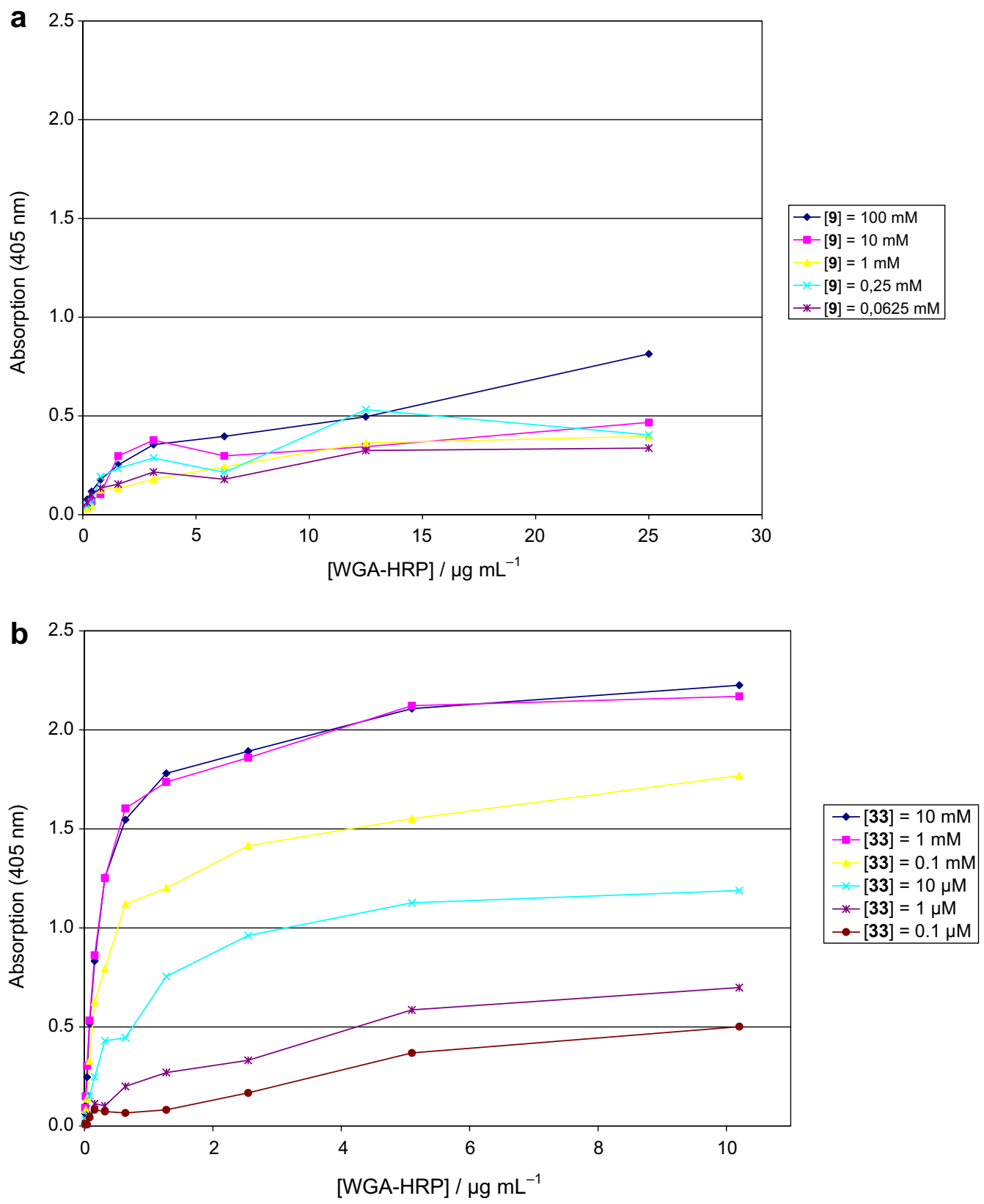

Figure 3. Binding of WGA-HRP to covalently modified microtiter plates 31 containing a short linker (a) and $\mathbf{3 4}$ containing a long linker (b) prepared with varying concentrations of activated carbonate 9 and amine 33, respectively. Assays were carried out under identical conditions.

on the other. It was expected that the lower $\mathrm{IC}_{50}$ values would result from significantly lower binding affinities of the lectin to covalently modified plates 34 . The apparent dissociation constant $K_{\mathrm{D}}^{\mathrm{ELLA}}$ for the interaction of WGAHRP with surface 34, which corresponds to the concentration of WGA-HRP necessary to occupy $50 \%$ of the surface binding sites, was readily available from the binding curves shown in Figure 3b. Data for the PSMcoated surface were obtained from an analogous experiment. As shown in the semi-logarithmic plot in Figure $5, K_{\mathrm{D}}^{\mathrm{ELA}}$ of covalently modified plates $34\left(0.26 \mu \mathrm{g} \mathrm{mL}{ }^{-1}\right)$ is even slightly lower than $K_{\mathrm{D}}^{\mathrm{ELLA}}$ of PSM-coated plates $\left(0.35 \mu \mathrm{g} \mathrm{mL}^{-1}\right)$ which corresponds to a higher binding affinity and does not explain the observed lower $\mathrm{IC}_{50}$ values with surface 34. A closer examination of the bind- ing curves reveals two differences. Whereas the binding curve for covalently modified plates $\mathbf{3 4}$ perfectly fits to a Langmuir isotherm (Hill coefficient $=1$ ), the binding curve for PSM-coated plates is much steeper with a Hill coefficient of 2. At the same time, PSM-coated plates were estimated to bind roughly twice the amount of WGA-HRP per unit surface area compared with surface 34. These results underline the importance of the topology of carbohydrate presentation on surfaces, such as cell membranes or carbohydrate microarrays, for the affinity and specificity of carbohydrate-lectin interactions. At this point, it is worth mentioning that the $\mathrm{IC}_{50}$ value of GlcNAc determined by the new assay $(23 \mathrm{mM})$ is in much closer proximity to the $K_{\mathrm{D}}$ value of GlcNAc which has been determined by several groups 


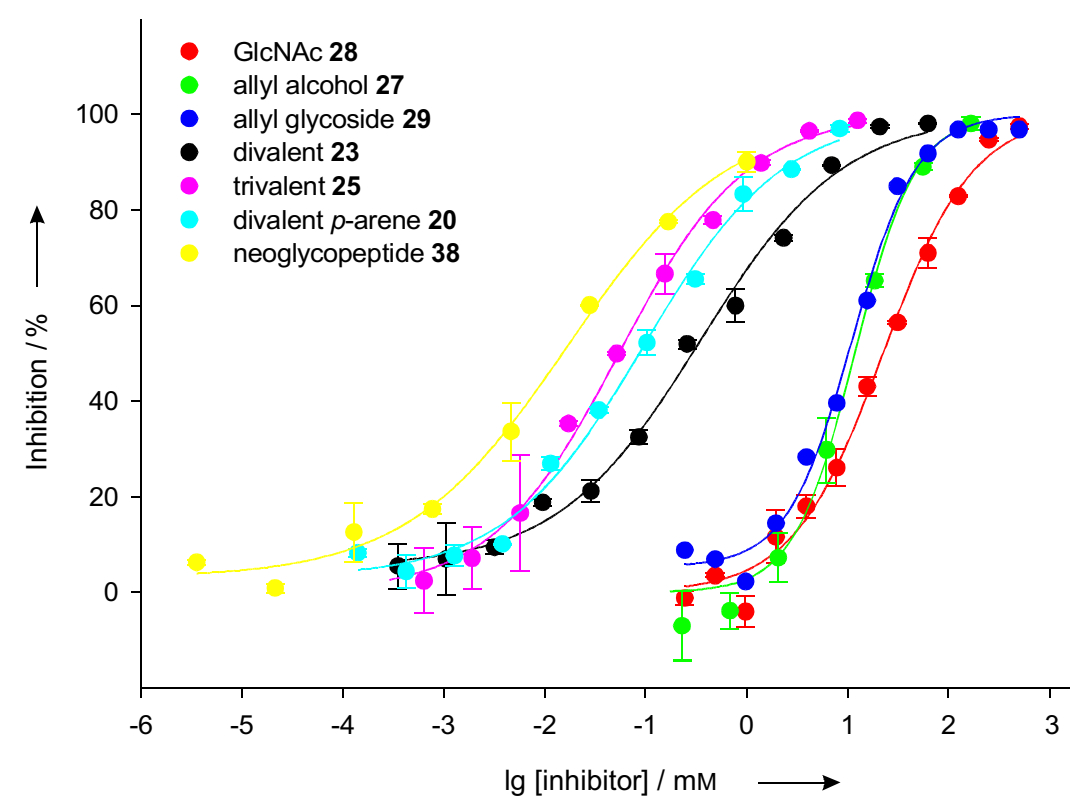

Figure 4. Dose-response curves for inhibition of the binding of HRP-labeled WGA to covalently modified microtiter plates $\mathbf{3 4}$ by synthetic ligands $20,23,25,27-29$, and 38 .

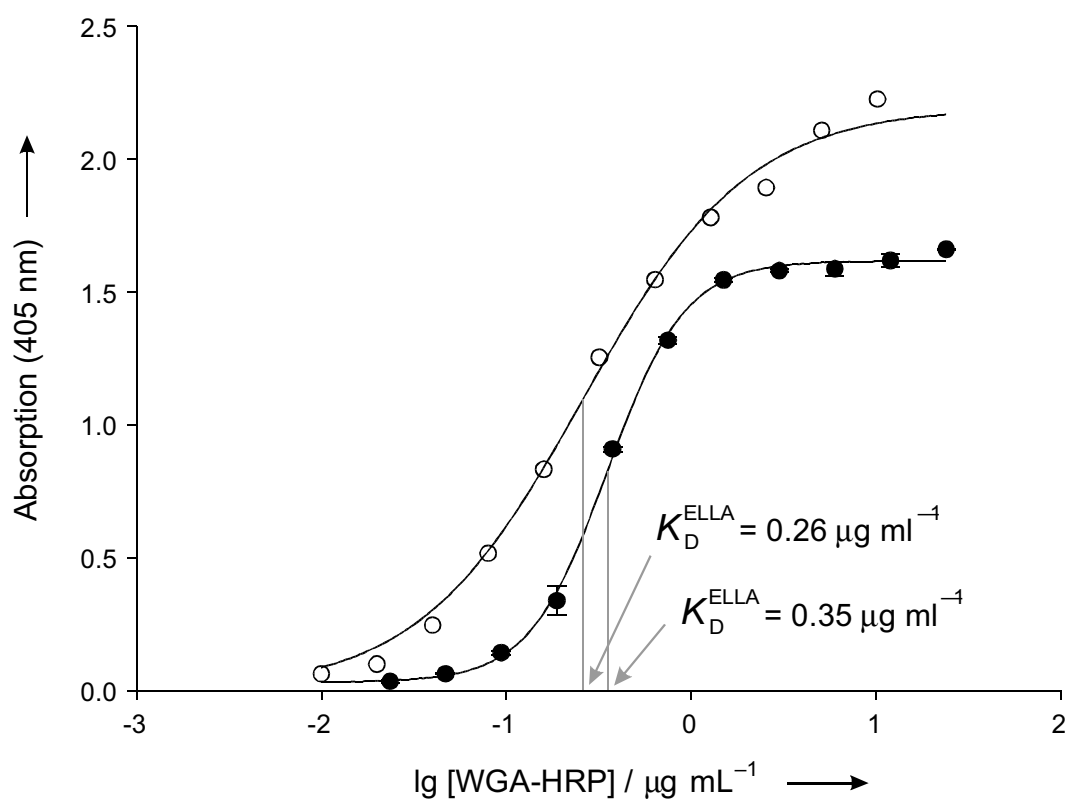

Figure 5. Semi-logarithmic plot of the binding of WGA-HRP to (•) PSM-coated microtiter plates and (o) covalently modified microtiter plates 34 produced with a concentration of GlcNAc derivative 33 of $1 \mathrm{mM}$. Absolute absorption values are not comparable for both experiments due to different assay conditions. PSM-coated plates were estimated to bind roughly twice the amount of WGA-HRP per unit surface area compared with microtiter plates 34 .

employing different methods ${ }^{54-58}$ to be in the range of approximately $1-5 \mathrm{mM}$.

As mentioned in the introduction, a disadvantage of ELLA is that in many cases maximal inhibition occurs at considerably less than $100 \%$. When we, for example, determined the $\mathrm{IC}_{50}$ values of cyclic neoglycopeptides, such as 38, for inhibition of WGA-HRP binding to PSM-coated microtiter plates, a maximum inhibition of approximately $70 \%$ was observed. ${ }^{38}$ The reasons for this behavior are obscure but might be rooted in the presence of several different binding sites on PSM which is a highly glycosylated glycoprotein existing in many glycoforms. It is known that WGA also binds to $N$-acetylneuraminic acid ${ }^{39}$ and it may be that this interaction is not inhibited by GlcNAc derivatives. Therefore, we subjected 38 to the ELLA with covalently immobilized GlcNAc. As can be seen in Figure 4, the maximal inhibition of WGA-HRP binding to this surface presenting a homogeneous carbohydrate epitope is now close to $100 \%$. The $\mathrm{IC}_{50}$ value of 38 is $16 \mu \mathrm{M}$ corresponding to a $\beta$ of 1440 (Table 2). The previously determined $\mathrm{IC}_{50}$ employing PSM-coated microtiter plates was $0.38 \mathrm{mM}$ $(\beta=218){ }^{38,59}$ 


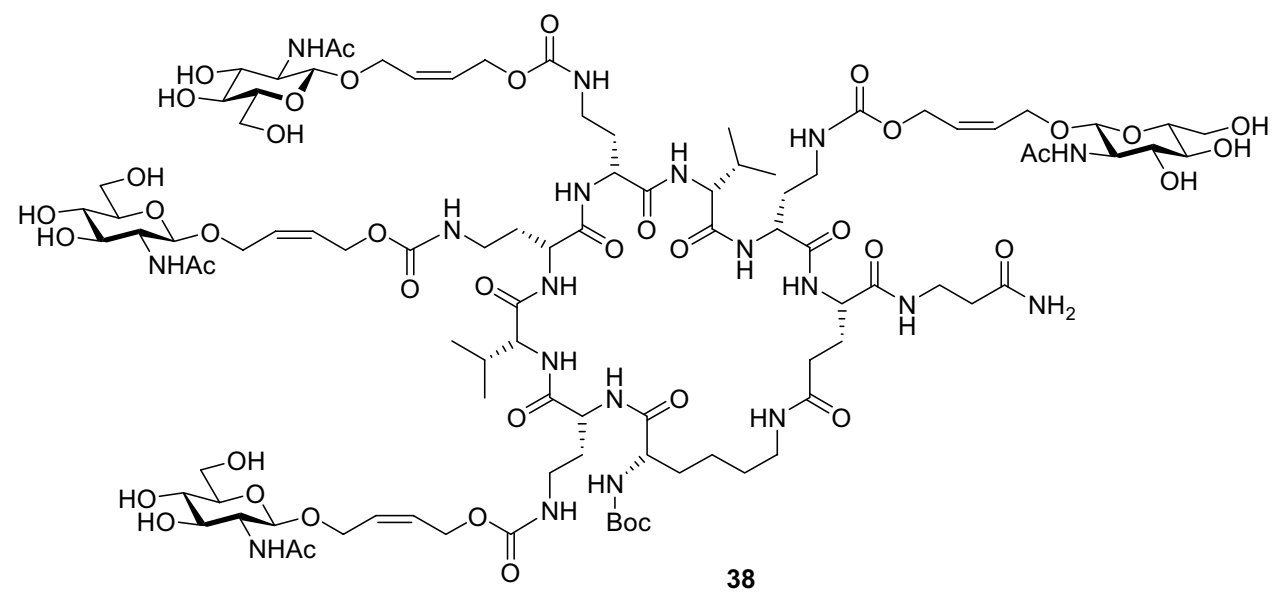

\section{Conclusions}

In conclusion, synthetic mono- to tetravalent WGA ligands have been examined for their ability to inhibit binding of WGA-HRP to carbohydrate-coated microtiter plates. $\mathrm{IC}_{50}$ values have been determined by an ELLA with non-covalently immobilized PSM as reference ligand and an ELLA employing covalently immobilized spacer-separated GlcNAc as reference ligand. In general, the inhibitory potency of the ligands increased with the number of GlcNAc residues without a clear preference for a certain spacer. Comparison of the results of both ELLA, however, indicated that the type of presentation of GlcNAc residues on the microtiter plates either as part of a glycoprotein or as a covalently immobilized monosaccharide derivative strongly influences the outcome of the assay. Our investigations revealed two remarkable aspects. Interestingly, although the apparent dissociation constants $K_{\mathrm{D}}^{\mathrm{ELLA}}$ for the interaction of WGA-HRP with the microtiter plates are comparable for both surfaces, $\mathrm{IC}_{50}$ values obtained with the PSM-free ELLA were substantially lower. Furthermore, this ELLA displays a better differentiation between ligands of different valency leading to significantly higher relative inhibitory potencies ( $\beta$ values) of multivalent ligands. Covalent immobilization of carbohydrate derivative 33 allows for generation of a chemically defined carbohydrate presentation. Problems associated with the use of PSM, such as maximum inhibition at considerably less than $100 \%$, poor reproducibility of $\mathrm{IC}_{50}$ values, and insufficient solubility of the inhibitors at the concentrations required for maximum inhibition, could be overcome with this ELLA.

\section{Experimental}

\subsection{General methods}

Solvents were purified by distillation and dried by normal procedures. Thin-layer chromatography (TLC) was performed on Merck silica gel $60 \mathrm{~F}_{254}$ aluminum sheets. The sheets were visualized by UV light and immersion in the appropriate stain followed by heating.
Preparative flash column chromatography (FC) was carried out on Merck silica gel $60(40-63 \mu \mathrm{m}) .{ }^{1} \mathrm{H}$ NMR and ${ }^{13} \mathrm{C}$ NMR spectra were recorded on Bruker $\mathrm{AC}$ 250, Bruker AMX 400, and Bruker Avance DRX 600 instruments. ${ }^{1} \mathrm{H}$ chemical shifts are reported in ppm relative to the signal from residual solvent protons $\left(\mathrm{CDCl}_{3}\right.$ : 7.26; $\left.\mathrm{D}_{2} \mathrm{O}: 4.67 \mathrm{ppm}\right) .{ }^{13} \mathrm{C}$ chemical shifts are referenced to the solvent signal $\left(\mathrm{CDCl}_{3}: 77.0 \mathrm{ppm}\right)$ or in case of $\mathrm{D}_{2} \mathrm{O}$ to internal standard $\left[\mathrm{D}_{3}\right] \mathrm{MeCN}(1.32 \mathrm{ppm})$. Assignments of proton and carbon signals were carried out with the aid of DQF-COSY, HMQC, and ROESY experiments. MALDI mass spectra were obtained on a Bruker Biflex III instrument with $\alpha$-cyano-4-hydroxycinnamic acid (CHCA) as the matrix (positive mode). High resolution nano-ESI mass spectra were recorded on an Bruker Apex II FT-ICR mass spectrometer equipped with a $7 \mathrm{~T}$ actively shielded cryomagnet and an Apollo ESI source. Samples were dissolved in water/MeOH 1:1 (v/v) to a final concentration of $5 \mathrm{pmol} \mu \mathrm{L}^{-1}$. If required, a solution of $40 \mathrm{mg} \mathrm{mL}^{-1}$ $\mathrm{NaI}$ in $\mathrm{MeOH}$ was added to the sample solutions in a ratio of 1:200 (v/v). Elemental analyses were performed by the microanalytical facility at the Universität Konstanz.

\subsection{Synthesis of the WGA ligands}

4.2.1. General procedure 1 (GP 1): preparation of the acetylated WGA ligands. [(Z)-4-( $p$-Nitrophenoxycarbonyloxy)-but-2-en-1-yl]-2-acetamido-3,4,6-tri- $O$-acetyl-2deoxy- $\beta$-D-glucopyranoside $\mathbf{9}^{42}$ (1.1 equiv per amino group) is dissolved in dry $\mathrm{CH}_{2} \mathrm{Cl}_{2}(3-11 \mathrm{~mL}$ per mmol 9). Addition of the amine and $\mathrm{EtN}(i-\mathrm{Pr})_{2}$ (1 equiv base per amino group) affords a yellow colored solution. The reaction mixture is stirred at room temperature until the reaction is complete. After evaporation of the solvent, the residue is purified by FC.

4.2.2. General procedure 2 (GP 2): deprotection of the acetylated WGA ligands. The acetylated WGA ligand is dissolved in $\mathrm{MeOH} / \mathrm{EtNMe}_{2}$ 5:1 (20-30 $\mathrm{mL}$ per $\mathrm{mmol}$ acetylated compound) and stirred at room temperature until the deacetylation is complete. Evaporation of the solvent gives the product in sufficient purity for further reactions. 
4.2.3. 4-(2-Acetamido-3,4,6-tri- $O$-acetyl-2-deoxy- $\beta$-Dglucopyranosyloxy)-( $Z$ )-but-2-enyloxycarbonyl-propylamine (10). According to GP 1, $9(320 \mathrm{mg}, 0.55 \mathrm{mmol})$, $\mathrm{CH}_{2} \mathrm{Cl}_{2}(5 \mathrm{~mL})$, propylamine $(41 \mu \mathrm{L}, 0.5 \mathrm{mmol})$, and $\mathrm{EtN}(i-\mathrm{Pr})_{2}(87 \mu \mathrm{L}, 0.5 \mathrm{mmol})$ were reacted overnight. FC $\left(\mathrm{CH}_{2} \mathrm{Cl}_{2} / \mathrm{MeOH} 30: 1\right)$ gave $10(213 \mathrm{mg}, 85 \%)$ as a white solid. $R_{\mathrm{f}}=0.32\left(\mathrm{CH}_{2} \mathrm{Cl}_{2} / \mathrm{MeOH} 15: 1\right) ;{ }^{1} \mathrm{H} \mathrm{NMR}$ $\left(600.1 \mathrm{MHz}, \mathrm{CDCl}_{3}, 20^{\circ} \mathrm{C}\right): \delta=5.84(\mathrm{~d}, J=8.2 \mathrm{~Hz}$, $1 \mathrm{H}$; NHAc), 5.73-5.66 (m, 2H; $\left.\mathrm{H}_{\text {vinyl }}\right), 5.27$ (' $\mathrm{t}$ ', $J=9.8 \mathrm{~Hz}, 1 \mathrm{H} ; \mathrm{H}-3), 5.06$ ('t', $J=9.6 \mathrm{~Hz}, 1 \mathrm{H} ; \mathrm{H}-4)$, 4.86 (br s, 1H; NH), 4.74 (d, $J=8.3 \mathrm{~Hz}, 1 \mathrm{H} ; \mathrm{H}-1)$, 4.63-4.61 (m, 2H; $\left.\mathrm{H}_{\text {allyl }}\right), 4.36(\mathrm{dd}, J=12.9,5.1 \mathrm{~Hz}$, $\left.1 \mathrm{H} ; \mathrm{H}_{\text {allyl }}\right), 4.30$ (dd, $\left.J=12.9,6.8 \mathrm{~Hz}, 1 \mathrm{H} ; \mathrm{H}_{\text {allyl }}\right), 4.24$ $(\mathrm{dd}, J=12.2,4.6 \mathrm{~Hz}, 1 \mathrm{H} ; \mathrm{H}-6 \mathrm{a}), 4.14$ (dd, $J=12.2$, $1.5 \mathrm{~Hz}, 1 \mathrm{H}$; H-6b), 3.91-3.88 (m, 1H; H-2), 3.72-3.70 (m, 1H; H-5), 3.14-3.13 (m, 2H; $\left.\mathrm{CH}_{2} \mathrm{CH}_{2} \mathrm{CH}_{3}\right), 2.08$ $\left(\mathrm{s}, 3 \mathrm{H} ; \mathrm{C}(\mathrm{O}) \mathrm{CH}_{3}\right), 2.02\left(\mathrm{~s}, 3 \mathrm{H} ; \mathrm{C}(\mathrm{O}) \mathrm{CH}_{3}\right), 2.01(\mathrm{~s}, 3 \mathrm{H}$; $\left.\mathrm{C}(\mathrm{O}) \mathrm{CH}_{3}\right), 1.93$ (s, 3H; $\left.\mathrm{C}(\mathrm{O}) \mathrm{CH}_{3}\right), 1.54-1.50(\mathrm{~m}, 2 \mathrm{H}$; $\left.\mathrm{CH}_{2} \mathrm{CH}_{2} \mathrm{CH}_{3}\right), \quad 0.92 \mathrm{ppm} \quad(\mathrm{t}, \quad J=7.4 \mathrm{~Hz}, \quad 3 \mathrm{H}$; $\left.\mathrm{CH}_{2} \mathrm{CH}_{2} \mathrm{CH}_{3}\right) ;{ }^{13} \mathrm{C}$ NMR (150.9 $\mathrm{MHz}, \mathrm{CDCl}_{3}, 20^{\circ} \mathrm{C}$ ): $\delta=170.8, \quad 170.8, \quad 170.3, \quad 169.4 \quad\left(\mathrm{C}(\mathrm{O}) \mathrm{CH}_{3}\right), \quad 156.4$ $(\mathrm{OC}(\mathrm{O}) \mathrm{NH}), 128.8\left(\mathrm{C}_{\text {olefin. }}\right), 128.6\left(\mathrm{C}_{\text {olefin. }}\right), 99.5(\mathrm{C}-1)$, 72.5 (C-3), $71.8(\mathrm{C}-5), 68.6(\mathrm{C}-4), 64.6\left(\mathrm{C}_{\mathrm{allyl}}\right), 62.1(\mathrm{C}-$ 6), $60.4\left(\mathrm{C}_{\text {allyl }}\right), 54.6(\mathrm{C}-2), 42.8\left(\mathrm{CH}_{2} \mathrm{CH}_{2} \mathrm{CH}_{3}\right), 23.3$ $\left(\mathrm{C}(\mathrm{O}) \mathrm{CH}_{3}\right), 23.2 \quad\left(\mathrm{CH}_{2} \mathrm{CH}_{2} \mathrm{CH}_{3}\right), 20.7,20.7,20.6$ $\left(\mathrm{C}(\mathrm{O}) \mathrm{CH}_{3}\right), 11.2 \mathrm{ppm}\left(\mathrm{CH}_{2} \mathrm{CH}_{2} \mathrm{CH}_{3}\right)$; elemental analysis calcd (\%) for $\mathrm{C}_{22} \mathrm{H}_{34} \mathrm{~N}_{2} \mathrm{O}_{11}$ (502.51): C, 52.58; $\mathrm{H}$, 6.82; N, 5.57; found: C, 52.62; H, 6.75; N, 5.55.

4.2.4. 4-(2-Acetamido-3,4,6-tri- $O$-acetyl-2-deoxy- $\beta$-D-glucopyranosyloxy)-( $Z$ )-but-2-enyloxycarbonyl-benzyl-amine (11). According to GP 1,9 (291 mg, $0.5 \mathrm{mmol}), \mathrm{CH}_{2} \mathrm{Cl}_{2}$ $(1.5 \mathrm{~mL})$, benzylamine $(60 \mu \mathrm{L}, 0.55 \mathrm{mmol})$, and $\operatorname{EtN}(i-$ $\mathrm{Pr})_{2}(87 \mu \mathrm{L}, 0.5 \mathrm{mmol})$ were reacted overnight. FC (EtOAc) gave 11 (258 mg, 94\%) as a slight brown solid. $R_{\mathrm{f}}=0.27 \quad$ (EtOAc); ${ }^{1} \mathrm{H} \quad \mathrm{NMR} \quad\left(600.1 \mathrm{MHz}, \mathrm{CDCl}_{3}\right.$, $\left.20{ }^{\circ} \mathrm{C}\right): \delta=7.35-7.28\left(\mathrm{~m}, 5 \mathrm{H} ; \mathrm{H}_{\mathrm{ar}}\right), 5.82(\mathrm{~d}, J=8.7 \mathrm{~Hz}$, $1 \mathrm{H} ; \mathrm{NHAc}), \quad 5.74-5.66\left(\mathrm{~m}, 2 \mathrm{H} ; \mathrm{H}_{\text {vinyl }}\right), 5.27$ ('t', $J=10.0 \mathrm{~Hz}, 1 \mathrm{H} ; \mathrm{H}-3), 5.25$ (br s, $1 \mathrm{H} ; \mathrm{NH}), 5.06$ ('t', $J=9.6 \mathrm{~Hz}, 1 \mathrm{H}$; H-4), 4.73 (d, $J=8.3 \mathrm{~Hz}, 1 \mathrm{H} ; \mathrm{H}-1), 4.70$ $4.61\left(\mathrm{~m}, 2 \mathrm{H} ; \mathrm{H}_{\text {allyl }}\right), 4.37-4.29\left(\mathrm{~m}, 4 \mathrm{H} ; \mathrm{H}_{\text {allyl }}, \mathrm{CH}_{2} \mathrm{~N}\right)$, 4.23 (dd, $J=12.2,4.7 \mathrm{~Hz}, 1 \mathrm{H} ; \mathrm{H}-6 \mathrm{a}), 4.13$ (dd, $J=12.2$, $1.55 \mathrm{~Hz}, 1 \mathrm{H}$; H-6b), 3.88 ('q', $J=9.2 \mathrm{~Hz}, 1 \mathrm{H}$; H-2), 3.703.69 (m, 1H; H-5), 2.07 (s, 3H; C(O)CH $), 2.02$ (s, 3H; $\left.\mathrm{C}(\mathrm{O}) \mathrm{CH}_{3}\right), 2.01$ (s, 3H; $\left.\mathrm{C}(\mathrm{O}) \mathrm{CH}_{3}\right), 1.90 \mathrm{ppm}(\mathrm{s}, 3 \mathrm{H}$; $\left.\mathrm{C}(\mathrm{O}) \mathrm{CH}_{3}\right) ;{ }^{13} \mathrm{C}$ NMR $\left(150.9 \mathrm{MHz}, \mathrm{CDCl}_{3}, \quad 20^{\circ} \mathrm{C}\right)$ : $\delta=170.8, \quad 170.6, \quad 170.3, \quad 169.4 \quad\left(C(\mathrm{O}) \mathrm{CH}_{3}\right), \quad 156.4$ (OC(O)NH), $138.3\left(\mathrm{C}_{\mathrm{ar}, \mathrm{q}}\right), 128.8\left(\mathrm{C}_{\text {olefin }}\right), 128.7\left(\mathrm{C}_{\text {olefin. }}\right)$, 128.6, 127.5, $127.4\left(\mathrm{C}_{\mathrm{ar}}\right), 99.4(\mathrm{C}-1), 72.5(\mathrm{C}-3), 71.7(\mathrm{C}-$ 5), 68.5 (C-4), $64.5\left(\mathrm{C}_{\text {allyl }}\right), 62.1$ (C-6), $60.7\left(\mathrm{C}_{\text {allyl }}\right), 54.6$ $(\mathrm{C}-2), \quad 45.0 \quad\left(\mathrm{CH}_{2} \mathrm{~N}\right), \quad 23.3, \quad 20.7, \quad 20.7, \quad 20.6 \mathrm{ppm}$ $\left(\mathrm{C}(\mathrm{O}) \mathrm{CH}_{3}\right)$; elemental analysis calcd (\%) for $\mathrm{C}_{26} \mathrm{H}_{34} \mathrm{~N}_{2} \mathrm{O}_{11}$ (550.55): C, 56.72; H, 6.22; N, 5.09; found: C, 56.41; H, 6.08; N, 5.11.

4.2.5. $\quad N, N^{\prime}$-Bis-(4-(2-acetamido-3,4,6-tri- $O$-acetyl-2deoxy- $\beta$-D-glucopyranosyloxy)-( $Z$ )-but-2-enyloxycarbonyl)-p-xylylenediamine (12). According to GP 1, 9 (256 mg, $0.44 \mathrm{mmol}), \mathrm{CH}_{2} \mathrm{Cl}_{2}$ (4 mL), p-xylylenediamine $(28 \mathrm{mg}$, $0.2 \mathrm{mmol})$ in $\mathrm{CH}_{2} \mathrm{Cl}_{2}(1 \mathrm{~mL})$, and $\operatorname{EtN}(i-\mathrm{Pr})_{2}(70 \mu \mathrm{L}$, $0.4 \mathrm{mmol})$ were reacted for $4.5 \mathrm{~h}$. FC $\left(\mathrm{CH}_{2} \mathrm{Cl}_{2} / \mathrm{MeOH}\right.$ 15:1) gave $12(199 \mathrm{mg}, 97 \%)$ as a white solid. $R_{\mathrm{f}}=0.18$ $\left(\mathrm{CH}_{2} \mathrm{Cl}_{2} / \mathrm{MeOH} \quad 15: 1\right) ; \quad{ }^{1} \mathrm{H} \quad \mathrm{NMR} \quad(600.1 \mathrm{MHz}$,
$\left.\mathrm{CDCl}_{3}+5 \% \mathrm{CD}_{3} \mathrm{OD}, 20^{\circ} \mathrm{C}\right): \delta=7.23$ (br s, $4 \mathrm{H} ; \mathrm{H}_{\mathrm{ar}}$ ), 5.67-5.66 (m, 4H; $\mathrm{H}_{\text {vinyl }}$ ), 5.20 ('t', $J=9.9 \mathrm{~Hz}, 2 \mathrm{H}$; H-3), 5.01 ('t', $J=9.6 \mathrm{~Hz}, 2 \mathrm{H} ; \mathrm{H}-4), 4.67$ (d, $J=8.2 \mathrm{~Hz}, 2 \mathrm{H}$; $\mathrm{H}-1)$, 4.64-4.63 (m, 2H; $\left.\mathrm{H}_{\text {allyl }}\right), 4.58-4.55$ (m, 2H; $\left.\mathrm{H}_{\text {allyl }}\right)$, 4.33-4.27 (m, 8H; $\left.\mathrm{CH}_{2} \mathrm{~N}, \mathrm{H}_{\text {allyl }}\right), 4.19(\mathrm{dd}, J=12.2$, $4.4 \mathrm{~Hz}, 2 \mathrm{H}$; H-6a), 4.11-4.01 (m, 2H; H-6b), 3.86-3.83 (m, 2H; H-2), 3.68 (br s, 2H; H-5), 2.11 (s, 6H; $\left.\mathrm{C}(\mathrm{O}) \mathrm{CH}_{3}\right), 2.06\left(\mathrm{~s}, \quad 6 \mathrm{H} ; \mathrm{C}(\mathrm{O}) \mathrm{CH}_{3}\right), 1.99 \quad(\mathrm{~s}, \quad 6 \mathrm{H}$; $\left.\mathrm{C}(\mathrm{O}) \mathrm{CH}_{3}\right), 1.86 \mathrm{ppm}$ (s, 6H; $\left.\mathrm{C}(\mathrm{O}) \mathrm{CH}_{3}\right) ;{ }^{13} \mathrm{C} \mathrm{NMR}$ $\left(150.9 \mathrm{MHz}, \mathrm{CDCl}_{3}+5 \% \mathrm{CD}_{3} \mathrm{OD}, 20^{\circ} \mathrm{C}\right): \delta=171.1$, 171,1 171.1, $169.6\left(\mathrm{C}(\mathrm{O}) \mathrm{CH}_{3}\right), 156.7(\mathrm{OC}(\mathrm{O}) \mathrm{NH}), 137.7$ $\left(\mathrm{C}_{\mathrm{ar}, \mathrm{q}}\right), 128.6\left(\mathrm{C}_{\text {olefin. }}\right), 128.4\left(\mathrm{C}_{\text {olefin. }}\right), 127.6\left(\mathrm{C}_{\mathrm{ar}}\right), 99.4$ (C-1), 73.7 (C-3), 71.5 (C-5), 68.6 (C-4), 64.5 (C $\left.\mathrm{C}_{\text {allyl }}\right)$, 62.1 (C-6), $60.7\left(\mathrm{C}_{\text {allyl }}\right), 54.1(\mathrm{C}-2), 44.4\left(\mathrm{CH}_{2} \mathrm{~N}\right), 22.7$, 20.6, 20.6, $20.5 \mathrm{ppm}\left(\mathrm{C}(\mathrm{O}) \mathrm{CH}_{3}\right)$; elemental analysis calcd (\%) for $\mathrm{C}_{46} \mathrm{H}_{62} \mathrm{~N}_{4} \mathrm{O}_{22}(1023.00)$ : C, 54.01; H, 6.11; N, 5.48; found: C, 53.60; H, 5.98; N, 5.45.

4.2.6. $N, N^{\prime}$-Bis-(4-(2-acetamido-3,4,6-tri- $O$-acetyl-2-deoxy$\beta$-D-glucopyranosyloxy)-( $Z$ )-but-2-enyloxy-carbonyl)-m-xylylenediamine (13). According to GP 1, 9 (256 mg, $0.44 \mathrm{mmol}), \mathrm{CH}_{2} \mathrm{Cl}_{2}(5 \mathrm{~mL}), m$-xylylenediamine $(26 \mu \mathrm{L}$, $0.2 \mathrm{mmol})$, and $\mathrm{EtN}(i \text {-Pr })_{2}(70 \mu \mathrm{L}, 0.4 \mathrm{mmol})$ were reacted for $4.5 \mathrm{~h}$. FC $\left(\mathrm{CH}_{2} \mathrm{Cl}_{2} / \mathrm{MeOH} 15: 1\right)$ gave 13 $(197 \mathrm{mg}, 96 \%)$ as a white solid. $R_{\mathrm{f}}=0.16\left(\mathrm{CH}_{2} \mathrm{Cl}_{2} / \mathrm{MeOH}\right.$ $15: 1) ;{ }^{1} \mathrm{H}$ NMR $\left(600.1 \mathrm{MHz}, \mathrm{CDCl}_{3}, 20^{\circ} \mathrm{C}\right): \delta=7.31-$ $7.18\left(\mathrm{~m}, 4 \mathrm{H} ; \mathrm{H}_{\mathrm{ar}}\right), 6.10(\mathrm{~d}, J=8.5 \mathrm{~Hz}, 2 \mathrm{H}$; NHAc), 5.74-5.69 (m, 4H; $\mathrm{H}_{\text {vinyl }}$ ), 5.49 (br s, 2H; NH), 5.24 ('t', $J=9.7 \mathrm{~Hz}, 2 \mathrm{H}$; H-3), 5.04 ('t', $J=9.4 \mathrm{~Hz}, 2 \mathrm{H}$; H-4), 4.73-4.59 (m, 6H; $\left.\mathrm{H}_{\text {allyl }}, \mathrm{H}-1\right), 4.42-4.33$ (m, 8H; $\mathrm{H}_{\text {allyl, }}$ $\left.\mathrm{CH}_{2} \mathrm{~N}\right), 4.22$ (dd, $\left.J=12.1,4.0 \mathrm{~Hz}, 2 \mathrm{H} ; \mathrm{H}-6 \mathrm{a}\right), 4.14-4.12$ (m, 2H; H-6b), 3.87 ('q', $J=9.3 \mathrm{~Hz}, 2 \mathrm{H}$; H-2), 3.68-3.67 $(\mathrm{m}, 2 \mathrm{H} ; \mathrm{H}-5), 2.07$ (s, 6H; $\left.\mathrm{C}(\mathrm{O}) \mathrm{CH}_{3}\right), 2.02$ (s, 6H; $\left.\mathrm{C}(\mathrm{O}) \mathrm{CH}_{3}\right), 2.01$ (s, 6H; $\left.\mathrm{C}(\mathrm{O}) \mathrm{CH}_{3}\right), 1.90 \mathrm{ppm}(\mathrm{s}, 6 \mathrm{H}$; $\left.\mathrm{C}(\mathrm{O}) \mathrm{CH}_{3}\right) ;{ }^{13} \mathrm{C}$ NMR $\left(150.9 \mathrm{MHz}, \mathrm{CDCl}_{3}, 20^{\circ} \mathrm{C}\right)$ : $\delta=170.9, \quad 170.8, \quad 170 . \quad 6, \quad 169.4 \quad\left(C(\mathrm{O}) \mathrm{CH}_{3}\right), \quad 156.5$ $(\mathrm{OC}(\mathrm{O}) \mathrm{NH}), 138.0\left(\mathrm{C}_{\mathrm{ar}, \mathrm{q}}\right), 129.0\left(\mathrm{C}_{\text {olefin. }}\right), 128.4,126.5$, $126.0\left(\mathrm{C}_{\mathrm{ar}}\right), 99.4$ (C-1), 72.5 (C-3), 71.6 (C-5), 68.6 (C-4), $64.5\left(\mathrm{C}_{\text {allyl }}\right), 62.1(\mathrm{C}-6), 60.7\left(\mathrm{C}_{\mathrm{allyl}}\right), 54.5(\mathrm{C}-2), 44.8$ $\left(\mathrm{CH}_{2} \mathrm{~N}\right), 23.2,20.8,20.7,20.7 \mathrm{ppm}\left(\mathrm{C}(\mathrm{O}) \mathrm{CH}_{3}\right)$; elemental analysis calcd $(\%)$ for $\mathrm{C}_{46} \mathrm{H}_{62} \mathrm{~N}_{4} \mathrm{O}_{22}$ (1023.00): $\mathrm{C}$, 54.01; H, 6.11; N, 5.48; found: C, 53.87; H, 6.29; N, 5.48.

4.2.7. 1,4-Bis-(3-(4-(2-acetamido-3,4,6-tri- $O$-acetyl-2-deoxy- $\beta$-D-glucopyranosyloxy)-( $Z$ )-but-2-enyloxy-carbonylamino)-propoxy)-butane (14). Corresponding to GP 1, 9 (256 mg, $0.44 \mathrm{mmol}), \mathrm{CH}_{2} \mathrm{Cl}_{2}(5 \mathrm{~mL}), 1$,4-bis-(3-aminopropoxy)-butane $(43 \mu \mathrm{L}, 0.2 \mathrm{mmol})$, and $\operatorname{EtN}(i-\mathrm{Pr})_{2}$ $(70 \mu \mathrm{L}, 0.4 \mathrm{mmol})$ were reacted for $3 \mathrm{~h}$. FC $\left(\mathrm{CH}_{2} \mathrm{Cl}_{2} /\right.$ $\mathrm{MeOH}$ 15:1) gave $14(182 \mathrm{mg}, 83 \%)$ as a white solid. $R_{\mathrm{f}}=0.18\left(\mathrm{CH}_{2} \mathrm{Cl}_{2} / \mathrm{MeOH} 15: 1\right) ;{ }^{1} \mathrm{H} \mathrm{NMR}(600.1 \mathrm{MHz}$, $\left.\mathrm{CDCl}_{3}, 20^{\circ} \mathrm{C}\right): \delta=6.03(\mathrm{~d}, J=6.9 \mathrm{~Hz}, 2 \mathrm{H}$; NHAc), 5.68 (br s, 4H; $\mathrm{H}_{\text {vinyl }}$ ), 5.33 (br s, 2H; NH), 5.27 (' $\mathrm{t}$ ', $J=9.9 \mathrm{~Hz}, 2 \mathrm{H} ; \mathrm{H}-3$ ), 5.06 ('t', $J=9.5 \mathrm{~Hz}, 2 \mathrm{H}$; H-4), 4.74 (d, $J=8.3 \mathrm{~Hz}, 2 \mathrm{H}$; H-1), 4.62-4.60 (m, 4H; $\left.\mathrm{H}_{\text {allyl }}\right)$, 4.37 (dd, $J=12.6,4.0 \mathrm{~Hz}, 2 \mathrm{H}$; $\left.\mathrm{H}_{\text {allyl }}\right), 4.30-4.24$ (m, 4H; H-6a, $\mathrm{H}_{\text {allyl }}$ ), 4.14 (br d, $J=12.0 \mathrm{~Hz}, 2 \mathrm{H}$; H-6b), 3.89 ('q', $J=9.1 \mathrm{~Hz}, 2 \mathrm{H}, \mathrm{H}-2), 3.72-3.71$ (m, 2H; H-5), 3.49 (br s, $4 \mathrm{H} ; \mathrm{NCH}_{2} \mathrm{CH}_{2} \mathrm{CH}_{2} \mathrm{O}$ ), 3.43 (br s, $4 \mathrm{H} ; \mathrm{CH}_{2}$ ), 3.283.27 (m, 4H; $\left.\mathrm{NCH}_{2} \mathrm{CH}_{2} \mathrm{CH}_{2} \mathrm{O}\right), 2.08\left(\mathrm{~s}, 6 \mathrm{H} ; \mathrm{C}(\mathrm{O}) \mathrm{CH}_{3}\right.$ ), 2.02 (s, 6H; $\left.\mathrm{C}(\mathrm{O}) \mathrm{CH}_{3}\right), 2.01\left(\mathrm{~s}, 6 \mathrm{H} ; \mathrm{C}(\mathrm{O}) \mathrm{CH}_{3}\right), 1.93$ (s, $\left.6 \mathrm{H} ; \mathrm{C}(\mathrm{O}) \mathrm{CH}_{3}\right), 1.77$ (br s, 4H; $\mathrm{NCH}_{2} \mathrm{CH}_{2} \mathrm{CH}_{2} \mathrm{O}$ ), $1.62 \mathrm{ppm}$ (br s, 4H; $\left.\mathrm{CH}_{2}\right) ;{ }^{13} \mathrm{C} \mathrm{NMR}$ (150.9 MHz, 
$\left.\mathrm{CDCl}_{3}\right): \quad \delta=170.8 \quad 170.4, \quad 169.4 \quad\left(\mathrm{C}(\mathrm{O}) \mathrm{CH}_{3}\right), \quad 156.4$ $(\mathrm{OC}(\mathrm{O}) \mathrm{NH}), 128.8\left(\mathrm{C}_{\text {olefin. }}\right), 128.5$ ( $\left.\mathrm{C}_{\text {olefin. }}\right), 99.6(\mathrm{C}-1)$, 72.6 (C-3), 71.8 (C-5), $70.8\left(\mathrm{CH}_{2}\right), 69.2\left(\mathrm{NCH}_{2} \mathrm{CH}_{2} \mathrm{CH}_{2} \mathrm{O}\right)$, $68.6(\mathrm{C}-4), 64.6\left(\mathrm{C}_{\text {allyl }}\right), 62.1(\mathrm{C}-6), 60.4\left(\mathrm{C}_{\text {allyl }}\right), 54.6(\mathrm{C}-2)$, $39.4\left(\mathrm{NCH}_{2} \mathrm{CH}_{2} \mathrm{CH}_{2} \mathrm{O}\right), 29.5\left(\mathrm{NCH}_{2} \mathrm{CH}_{2} \mathrm{CH}_{2} \mathrm{O}\right), 26.4$ $\left(\mathrm{CH}_{2}\right), 23.2,20.7,20.7,20.6 \mathrm{ppm}\left(\mathrm{C}(\mathrm{O}) \mathrm{CH}_{3}\right)$; elemental analysis calcd (\%) for $\mathrm{C}_{48} \mathrm{H}_{74} \mathrm{~N}_{4} \mathrm{O}_{24}$ (1091.11): C, 52.84; H, 6.84; N, 5.13; found: C, 52.53; H, 6.81; N, 5.06.

4.2.8. $N, N^{\prime}$-Bis-(4-(2-acetamido-3,4,6-tri- $O$-acetyl-2-deoxy$\beta$-D-glucopyranosyloxy)-( $Z$ )-but-2-enyloxycarbonyl)-4,7,10trioxa-1,13-tridecanediamine (15). According to GP 1, 9 (256 mg, $0.44 \mathrm{mmol}), \mathrm{CH}_{2} \mathrm{Cl}_{2}$ (5 mL), 4,7,10-trioxa-1,13tridecanediamine $(44 \mu \mathrm{L}, 0.2 \mathrm{mmol})$, and $\operatorname{EtN}(i \text {-Pr })_{2}$ $(70 \mu \mathrm{L}, 0.4 \mathrm{mmol})$ were reacted for $3 \mathrm{~h}$. $\mathrm{FC}\left(\mathrm{CH}_{2} \mathrm{Cl}_{2} / \mathrm{MeOH}\right.$ 9:1) gave $15(204 \mathrm{mg}, 92 \%)$ as a white solid. $R_{\mathrm{f}}=0.34$ $\left(\mathrm{CH}_{2} \mathrm{Cl}_{2} / \mathrm{MeOH}\right.$ 9:1); ${ }^{1} \mathrm{H}$ NMR $\left(600.1 \mathrm{MHz}, \mathrm{CDCl}_{3}\right.$, $\left.20^{\circ} \mathrm{C}\right): \delta=6.28(\mathrm{~d}, J=8.6 \mathrm{~Hz}, 2 \mathrm{H}$; NHAc), 5.67 (m, 4H; $\mathrm{H}_{\text {vinyl }}$ ), 5.54 (br s, 2H; NH), 5.26 ('t', $J=9.9 \mathrm{~Hz}, 2 \mathrm{H}$; H-3), 5.06 ('t', $J=9.6 \mathrm{~Hz}, 2 \mathrm{H}$; H-4), 4.73 (d, $J=8.4 \mathrm{~Hz}, 2 \mathrm{H}$; H1), 4.63-4.55 (m, 4H; $\left.\mathrm{H}_{\text {allyl }}\right), 4.36(\mathrm{dd}, J=12.8,4.0 \mathrm{~Hz}$, $\left.2 \mathrm{H} ; \mathrm{H}_{\text {allyl }}\right), 4.29-4.23$ (m, 4H; $\left.\mathrm{H}_{\text {allyl }}, \mathrm{H}-6 \mathrm{a}\right), 4.13$ (dd, $J=12.2,1.4 \mathrm{~Hz}, 2 \mathrm{H}$; H-6b), 3.91 ('q', $J=9.3 \mathrm{~Hz}, 2 \mathrm{H}$; H2), 3.72-3.71 (m, 2H; H-5), 3.63-3.62 (m, 4H; $\mathrm{CH}_{2} \mathrm{CH}_{2}$ ), 3.59-3.58 (m, 4H; $\left.\mathrm{CH}_{2} \mathrm{CH}_{2}\right), 3.54(\mathrm{t}, J=5.4 \mathrm{~Hz}, 4 \mathrm{H}$; $\mathrm{NCH}_{2} \mathrm{CH}_{2} \mathrm{CH}_{2} \mathrm{O}$ ), $3.27 \quad$ ('q', $J=5.8 \mathrm{~Hz}, \quad 4 \mathrm{H}$; $\mathrm{NCH}_{2} \mathrm{CH}_{2} \mathrm{CH}_{2} \mathrm{O}$ ), 2.07 (s, 6H; $\left.\mathrm{C}(\mathrm{O}) \mathrm{CH}_{3}\right), 2.01$ (s, 6H; $\left.\mathrm{C}(\mathrm{O}) \mathrm{CH}_{3}\right), 2.01$ (s, 6H; $\left.\mathrm{C}(\mathrm{O}) \mathrm{CH}_{3}\right), 1.93$ (s, 6H; $\left.\mathrm{C}(\mathrm{O}) \mathrm{CH}_{3}\right)$, $1.76 \mathrm{ppm}$ ('t', $\left.J=5.9 \mathrm{~Hz}, 4 \mathrm{H} ; \mathrm{NCH}_{2} \mathrm{CH}_{2} \mathrm{CH}_{2} \mathrm{O}\right) ;{ }^{13} \mathrm{C}$ NMR $\left(150.9 \mathrm{MHz}, \mathrm{CDCl}_{3}, \quad 20^{\circ} \mathrm{C}\right): \delta=170.8, \quad 170.6$, 169.4,163.2 ( $\left.\mathrm{C}(\mathrm{O}) \mathrm{CH}_{3}\right), 156.4(\mathrm{OC}(\mathrm{O}) \mathrm{NH}), 128.7\left(\mathrm{C}_{\text {olefin. }}\right)$,

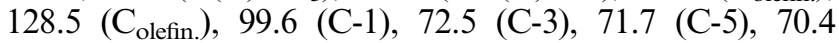
$\left(\mathrm{CH}_{2} \mathrm{CH}_{2}\right), 70.1\left(\mathrm{CH}_{2} \mathrm{CH}_{2}\right), 69.6\left(\mathrm{NCH}_{2} \mathrm{CH}_{2} \mathrm{CH}_{2} \mathrm{O}\right), 68.6$ (C-4), $64.6\left(\mathrm{C}_{\text {allyl }}\right), 62.1$ (C-6), 60.4 (C $\left.\mathrm{C}_{\text {allyl }}\right), 54.5$ (C-2), 39.2 $\left(\mathrm{NCH}_{2} \mathrm{CH}_{2} \mathrm{CH}_{2} \mathrm{O}\right), 29.3\left(\mathrm{NCH}_{2} \mathrm{CH}_{2} \mathrm{CH}_{2} \mathrm{O}\right), 23.2,20.7$, 20.7, $20.6 \mathrm{ppm}\left(\mathrm{C}(\mathrm{O}) \mathrm{CH}_{3}\right)$; elemental analysis calcd $(\%)$ for $\mathrm{C}_{48} \mathrm{H}_{74} \mathrm{~N}_{4} \mathrm{O}_{25}$ (1107.11): C, 52.07; H, 6.74; N, 5.06; found: C, 51.53; H, 6.69; N, 4.94 .

4.2.9. 1,7-Bis-(4-(2-acetamido-3,4,6-tri- $O$-acetyl-2-deoxy$\beta$-D-glucopyranosyloxy)-( $Z$ )-but-2-enyloxycarbonyl)-diethylenetriamine (16). According to GP 1, 9 (384 mg, $0.66 \mathrm{mmol}), \mathrm{CH}_{2} \mathrm{Cl}_{2}(2 \mathrm{~mL})$, diethylenetriamine $(32 \mu \mathrm{L}$, $0.3 \mathrm{mmol})$, and $\operatorname{EtN}(i-\operatorname{Pr})_{2}(105 \mu \mathrm{L}, 0.6 \mathrm{mmol})$ were reacted overnight. $\mathrm{FC}\left(\mathrm{CH}_{2} \mathrm{Cl}_{2} / \mathrm{MeOH} 9: 1\right)$ gave 16 (280 $\mathrm{mg}, 94 \%)$ as a white solid. $R_{\mathrm{f}}=0.15\left(\mathrm{CH}_{2} \mathrm{Cl}_{2} / \mathrm{MeOH}\right.$ 6:1); ${ }^{1} \mathrm{H}$ NMR (600.1 MHz, $\left.\mathrm{CDCl}_{3}, 20{ }^{\circ} \mathrm{C}\right): \delta=6.35(\mathrm{br}$ s, 2H; NHAc), 5.67 (br s, 4H; $\mathrm{H}_{\text {vinyl }}$ ), 5.58 (br s, 2H; $\mathrm{NH}$ ), 5.25 ('t', $J=9.9 \mathrm{~Hz}, 2 \mathrm{H} ; \quad \mathrm{H}-3), \quad 5.03 \quad$ ('t', $J=9.5 \mathrm{~Hz}, 2 \mathrm{H} ; \mathrm{H}-4), 4.73$ (d, $J=8.2 \mathrm{~Hz}, 2 \mathrm{H}$; H-1), 4.62-4.54 (m, 4H; $\left.\mathrm{H}_{\text {allyl }}\right), 4.22(\mathrm{dd}, J=12.2,4.3 \mathrm{~Hz}, 2 \mathrm{H}$; H-6a), 4.11-4.07 (m, 2H; H-6b), 3.89 (m, 2H; H-2), 3.73-3.72 (m, 2H; H-5), 3.26-3.25 (m, 4H; $\mathrm{CH}_{2} \mathrm{CH}_{2}$ ), 2.75 (br s, 4H; $\mathrm{CH}_{2} \mathrm{CH}_{2}$ ), 2.06 (s, 6H; C(O) $\left.\mathrm{CH}_{3}\right), 2.00$ $\left(\mathrm{s}, 6 \mathrm{H} ; \mathrm{C}(\mathrm{O}) \mathrm{CH}_{3}\right), 1.99$ (s, 6H; $\left.\mathrm{C}(\mathrm{O}) \mathrm{CH}_{3}\right), 1.91 \mathrm{ppm}(\mathrm{s}$, $\left.6 \mathrm{H} ; \mathrm{C}(\mathrm{O}) \mathrm{CH}_{3}\right) ;{ }^{13} \mathrm{C}$ NMR $\left(150.9 \mathrm{MHz}, \mathrm{CDCl}_{3}, 20^{\circ} \mathrm{C}\right)$ : $\delta=171.1, \quad 170.7, \quad 170.5, \quad 169.4 \quad\left(\mathrm{C}(\mathrm{O}) \mathrm{CH}_{3}\right), \quad 156.6$ $(\mathrm{OC}(\mathrm{O}) \mathrm{NH}), 128.9,128.4\left(\mathrm{C}_{\text {olefin. }}\right), 99.5(\mathrm{C}-1), 72.5(\mathrm{C}-$ 3), 71.6 (C-5), 68.6 (C-4), 64.5 (C $\left.\mathrm{C}_{\text {allyl }}\right), 62.1$ (C-6), 60.3 $\left(\mathrm{C}_{\text {allyl }}\right), 54.4(\mathrm{C}-2), 48.4\left(\mathrm{CH}_{2} \mathrm{CH}_{2}\right), 40.5\left(\mathrm{CH}_{2} \mathrm{CH}_{2}\right)$, 23.2, 21.0, 20.7, $20.6 \mathrm{ppm}\left(\mathrm{C}(\mathrm{O}) \mathrm{CH}_{3}\right)$; elemental analysis calcd (\%) for $\mathrm{C}_{42} \mathrm{H}_{63} \mathrm{~N}_{5} \mathrm{O}_{22}$ (989.97): C, 50.96; H, 6.41; N, 7.07; found: C, 51.11; H, 6.46; N, 6.67.
4.2.10. Tris-(2-(4-(2-acetamido-3,4,6-tri- $O$-acetyl-2-deoxy$\beta$-D-glucopyranosyloxy)-( $Z$ )-but-2-enyloxycarbonyl)-aminoethyl)-amine (17). Corresponding to GP 1, compound 9 (384 mg, $0.66 \mathrm{mmol}), \mathrm{CH}_{2} \mathrm{Cl}_{2}(5 \mathrm{~mL})$, tris-(2-aminoethyl)-amine $(30 \mu \mathrm{L}, 0.2 \mathrm{mmol})$, and $\operatorname{EtN}(i \text {-Pr })_{2}(105$ $\mu \mathrm{L}, 0.6 \mathrm{mmol})$ were reacted for $3.5 \mathrm{~h}$. FC $\left(\mathrm{CH}_{2} \mathrm{Cl}_{2} /\right.$ $\mathrm{MeOH}$ 9:1) gave 17 (292 mg, 99\%) as a white solid. $R_{\mathrm{f}}=0.31\left(\mathrm{CH}_{2} \mathrm{Cl}_{2} / \mathrm{MeOH} 9: 1\right) ;{ }^{1} \mathrm{H} \mathrm{NMR}(600.1 \mathrm{MHz}$, $\mathrm{CDCl}_{3}, 20^{\circ} \mathrm{C}$ ): $\delta=6.67$ (br s, $3 \mathrm{H}$; NHAc), 5.90 (br s, $3 \mathrm{H} ; \mathrm{NH}$ ), 5.68 (br s, $6 \mathrm{H} ; \mathrm{H}_{\mathrm{vinyl}}$ ), 5.25 ('t', $J=9.6 \mathrm{~Hz}$, $3 \mathrm{H} ; \mathrm{H}-3$ ), 5.05 ('t', $J=9.0 \mathrm{~Hz}, 3 \mathrm{H} ; \mathrm{H}-4), 4.72$ (d, $J=8.1 \mathrm{~Hz}$, 3H; H-1),4.63-4.55 (m, 6H; $\left.\mathrm{H}_{\text {allyl }}\right), 4.36$ 4.23 (m, 9H; $\left.\mathrm{H}_{\text {allyl }}, \mathrm{H}-6 \mathrm{a}\right), 4.14-4.12$ (m, 3H; H-6b), 3.96 ('q', $J=9.0 \mathrm{~Hz}, 3 \mathrm{H}$; H-2), 3.75-3.73 (m, 3H; H5), 3.21 (br s, 6H; $\mathrm{CH}_{2} \mathrm{CH}_{2}$ ), 2.55 (br s, 6H; $\mathrm{CH}_{2} \mathrm{CH}_{2}$ ), $2.07\left(\mathrm{~s}, 9 \mathrm{H} ; \mathrm{C}(\mathrm{O}) \mathrm{CH}_{3}\right), 2.00\left(\mathrm{~s}, 9 \mathrm{H} ; \mathrm{C}(\mathrm{O}) \mathrm{CH}_{3}\right), 2.00(\mathrm{~s}$, 9H; $\left.\mathrm{C}(\mathrm{O}) \mathrm{CH}_{3}\right), 1.92 \mathrm{ppm}\left(\mathrm{s}, 9 \mathrm{H} ; \mathrm{C}(\mathrm{O}) \mathrm{CH}_{3}\right) ;{ }^{13} \mathrm{C} \mathrm{NMR}$ $\left(150.9 \mathrm{MHz}, \mathrm{CDCl}_{3}, 20^{\circ} \mathrm{C}\right): \delta=170.9,170.8,170.6$, $169.4\left(\mathrm{C}(\mathrm{O}) \mathrm{CH}_{3}\right), \quad 156.9 \quad(\mathrm{OC}(\mathrm{O}) \mathrm{NH}), \quad 129.1,128.3$

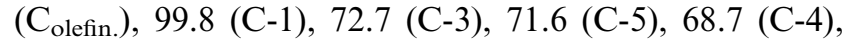
$64.6\left(\mathrm{C}_{\text {allyl }}\right), 62.1$ (C-6), $60.4\left(\mathrm{C}_{\text {allyl }}\right), 54.2(\mathrm{C}-2), 53.7$ $\left(\mathrm{CH}_{2} \mathrm{CH}_{2}\right), 38.8\left(\mathrm{CH}_{2} \mathrm{CH}_{2}\right), 23.2,20.7,20.7,20.6 \mathrm{ppm}$ $\left(\mathrm{C}(\mathrm{O}) \mathrm{CH}_{3}\right)$; elemental analysis calcd (\%) for $\mathrm{C}_{63} \mathrm{H}_{93} \mathrm{~N}_{7} \mathrm{O}_{33}$ (1476.44): $\mathrm{C}, 51.25 ; \mathrm{H}, 6.35 ; \mathrm{N}, 6.64$; found: C, 50.85; H, 6.44; N, 6.67.

4.2.11. 4-(2-Acetamido-2-deoxy- $\beta$-D-glucopyranosyloxy)(Z)-but-2-enyloxycarbonyl-propylamine (18). Corresponding to GP 2, 10 (190 mg, $378 \mu \mathrm{mol})$ was dissolved in $\mathrm{MeOH} / \mathrm{EtMe}_{2} \mathrm{~N}$ 5:1 and reacted for $48 \mathrm{~h}$. Compound 18 was obtained in quantitative yield as a white solid. $R_{\mathrm{f}}=0.54 \quad\left(\mathrm{MeCN} / \mathrm{H}_{2} \mathrm{O} \quad 4: 1\right) ;{ }^{1} \mathrm{H} \quad \mathrm{NMR} \quad(600.1 \mathrm{MHz}$, $\left.\mathrm{D}_{2} \mathrm{O}, 20{ }^{\circ} \mathrm{C}\right): \delta=5.73-5.68\left(\mathrm{~m}, 2 \mathrm{H} ; \mathrm{H}_{\text {vinyl }}\right), 4.55$ (br s, $\left.2 \mathrm{H} ; \mathrm{H}_{\text {allyl }}\right), 4.47$ (d, $\left.J=8.4 \mathrm{~Hz}, 1 \mathrm{H} ; \mathrm{H}-1\right), 4.33-4.25$ (m, 2H; $\mathrm{H}_{\text {allyl }}$ ), 3.84 (br d, $J=12.3 \mathrm{~Hz}, 1 \mathrm{H}$; H-6a), 3.68 (br d, $J=10.0 \mathrm{~Hz}, 1 \mathrm{H} ; \mathrm{H}-6 \mathrm{~b}), 3.62 \quad$ (' $\mathrm{t}$ ', $J=9.3 \mathrm{~Hz}, 1 \mathrm{H} ; \mathrm{H}-2), 3.46$ ('t', $J=8.2 \mathrm{~Hz}, 1 \mathrm{H} ; \mathrm{H}-3$ ), 3.39-3.37 (m, 2H; H-4, H-5), 3.00 (br s, 2H; $\left.\mathrm{NCH}_{2} \mathrm{CH}_{2} \mathrm{CH}_{3}\right), 1.96\left(\mathrm{~s}, 3 \mathrm{H} ; \mathrm{C}(\mathrm{O}) \mathrm{CH}_{3}\right), 1.43-1.39(\mathrm{~m}$, $\left.2 \mathrm{H} ; \quad \mathrm{NCH}_{2} \mathrm{CH}_{2} \mathrm{CH}_{3}\right), \quad 0.80 \mathrm{ppm}(\mathrm{t}, \quad J=7.2 \mathrm{~Hz}, 3 \mathrm{H}$; $\left.\mathrm{NCH}_{2} \mathrm{CH}_{2} \mathrm{CH}_{3}\right) ;{ }^{13} \mathrm{C}$ NMR (150.9 MHz, $\mathrm{D}_{2} \mathrm{O}, 20{ }^{\circ} \mathrm{C}$ ): $\delta=175.4\left(\mathrm{C}(\mathrm{O}) \mathrm{CH}_{3}\right), 158.0(\mathrm{OC}(\mathrm{O}) \mathrm{NH}), 129.8\left(\mathrm{C}_{\text {olefin }}\right)$, $129.4\left(\mathrm{C}_{\text {olefin. }}\right), 100.8(\mathrm{C}-1), 76.8$ (C-5 or C-4), $74.8(\mathrm{C}-3)$, 70.7 (C-4 or C-3), $65.5\left(\mathrm{C}_{\text {allyl }}\right) 61.7\left(\mathrm{C}_{\text {allyl }}\right), 61.6(\mathrm{C}-6)$, $56.4(\mathrm{C}-2), 43.1\left(\mathrm{NCH}_{2} \mathrm{CH}_{2} \mathrm{CH}_{3}\right), 23.2\left(\mathrm{C}(\mathrm{O}) \mathrm{CH}_{3}\right)$, $23.0\left(\mathrm{NCH}_{2} \mathrm{CH}_{2} \mathrm{CH}_{3}\right), \quad 11.3 \mathrm{ppm} \quad\left(\mathrm{NCH}_{2} \mathrm{CH}_{2} \mathrm{CH}_{3}\right)$; HRMS (nano ESI, pos. mode, $\mathrm{H}_{2} \mathrm{O} / \mathrm{MeOH}$ ) for $\mathrm{C}_{16} \mathrm{H}_{28} \mathrm{~N}_{2} \mathrm{O}_{8}$ : $[\mathrm{M}+\mathrm{H}]^{+}$calcd 377.1918; found: 377.1914, $[\mathrm{M}+\mathrm{Na}]^{+}$calcd 399.1738; found: 399.1737 .

4.2.12. 4-(2-Acetamido-2-deoxy- $\beta$-D-glucopyranosyloxy)(Z)-but-2-enyloxycarbonyl-benzylamine (19). 11 (214 mg, $389 \mu \mathrm{mol})$ was suspended in dry MeOH $(3 \mathrm{~mL})$. After addition of a $5.4 \mathrm{M}$ methanolic $\mathrm{NaOMe}$ solution (10 $\mu \mathrm{L}, 54 \mu \mathrm{mol})$ and stirring for $2.5 \mathrm{~h}$, the reaction mixture was neutralized using strong acidic ion exchanger

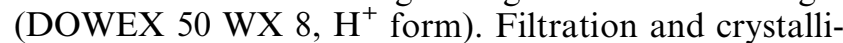
zation gave $19(148 \mathrm{mg}, 90 \%)$ as a slight yellow solid. $R_{\mathrm{f}}=0.67 \quad\left(\mathrm{MeCN} / \mathrm{H}_{2} \mathrm{O} \quad 4: 1\right) ;{ }^{1} \mathrm{H} \quad \mathrm{NMR} \quad(600.1 \mathrm{MHz}$, $\left.\mathrm{D}_{2} \mathrm{O}, 20{ }^{\circ} \mathrm{C}\right): \delta=7.35-7.34\left(\mathrm{~m}, 2 \mathrm{H} ; \mathrm{H}_{\mathrm{ar}}\right), 7.28-7.27(\mathrm{~m}$, $\left.3 \mathrm{H} ; \mathrm{H}_{\mathrm{ar}}\right), 5.74-5.68\left(\mathrm{~m}, 2 \mathrm{H} ; \mathrm{H}_{\text {vinyl }}\right), 4.57$ (br s, 2H; $\left.\mathrm{H}_{\text {allyl }}\right), 4.46(\mathrm{~d}, J=6.7 \mathrm{~Hz}, 1 \mathrm{H} ; \mathrm{H}-1), 4.30-4.24(\mathrm{~m}$, $4 \mathrm{H} ; \mathrm{H}_{\text {allyl }}, \mathrm{CH}_{2} \mathrm{~N}$ ), 3.83 (br d, $J=12.2 \mathrm{~Hz}, 1 \mathrm{H} ; \mathrm{H}-6 \mathrm{a}$ ), 
3.67-3.60 (m, 2H, H-6b, H-2), 3.46 ('t', $J=8.6 \mathrm{~Hz}, 1 \mathrm{H}$; $\mathrm{H}-3)$, 3.39-3.36 (m, 2H; H-4, H-5), $1.95 \mathrm{ppm}$ (s, 3H; $\left.\mathrm{C}(\mathrm{O}) \mathrm{CH}_{3}\right) ;{ }^{13} \mathrm{C}$ NMR $\left(150.9 \mathrm{MHz}, \quad \mathrm{D}_{2} \mathrm{O}, \quad 20^{\circ} \mathrm{C}\right)$ : $\delta=175.3\left(\mathrm{C}(\mathrm{O}) \mathrm{CH}_{3}\right), 159.2(\mathrm{OC}(\mathrm{O}) \mathrm{NH}), 138.0\left(\mathrm{C}_{\mathrm{ar}, \mathrm{q}}\right)$, $129.6\left(\mathrm{C}_{\text {olefin }}\right), 129.5\left(\mathrm{C}_{\text {olefin. }}\right), 128.3,127.9\left(\mathrm{C}_{\mathrm{ar}}\right), 100.7$ (C-1), 76.8 (C-5), 74.8 (C-3), 70.7 (C-4), $65.4\left(\mathrm{C}_{\text {allyl }}\right)$, $61.9\left(\mathrm{C}_{\text {allyl }}\right), 61.5(\mathrm{C}-6), 56.4(\mathrm{C}-2), 44.9\left(\mathrm{CH}_{2} \mathrm{~N}\right)$, $23.0 \mathrm{ppm}\left(\mathrm{C}(\mathrm{O}) \mathrm{CH}_{3}\right)$; HRMS (nano ESI, pos. mode, $\left.\mathrm{H}_{2} \mathrm{O} / \mathrm{MeOH}\right)$ for $\mathrm{C}_{20} \mathrm{H}_{28} \mathrm{~N}_{2} \mathrm{O}_{8}: \quad[\mathrm{M}+\mathrm{Na}]^{+}$calcd 447.1738; found: 447.1743 .

4.2.13. $N, N^{\prime}$-Bis-(4-(2-acetamido-2-deoxy- $\beta$-d-glucopyranosyloxy)-(Z)-but-2-enyloxycarbonyl)-p-xylylenediamine (20). Compound $12(190 \mathrm{mg}, 186 \mu \mathrm{mol})$ was dissolved in $\mathrm{MeOH} / \mathrm{CHCl}_{3} \quad 1: 1 \quad(5 \mathrm{~mL})$ and a $5.4 \mathrm{M}$ methanolic $\mathrm{NaOMe}$ solution $(5 \mu \mathrm{L}, 27 \mu \mathrm{mol})$ was added upon which a white precipitate formed. After stirring for $2.5 \mathrm{~h}$, water was added until the precipitate disappeared. The reaction mixture was neutralized using strong acidic ion exchanger

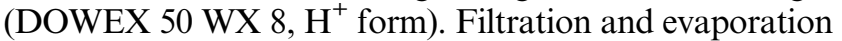
gave $20(142 \mathrm{mg}, 99 \%)$ as a white solid. $R_{\mathrm{f}}=0.35(\mathrm{MeCN} /$ $\left.\mathrm{H}_{2} \mathrm{O} 4: 1\right) ;{ }^{1} \mathrm{H}$ NMR $\left(600.1 \mathrm{MHz}, \mathrm{D}_{2} \mathrm{O}, 20^{\circ} \mathrm{C}\right): \delta=7.21$ (br s, $\left.4 \mathrm{H} ; \mathrm{H}_{\mathrm{ar}}\right), 5.71-5.66\left(\mathrm{~m}, 4 \mathrm{H} ; \mathrm{H}_{\mathrm{vinyl}}\right), 4.55$ (br s, $4 \mathrm{H}$; $\left.\mathrm{H}_{\text {allyl }}\right), 4.45(\mathrm{~d}, J=6.7 \mathrm{~Hz}, 2 \mathrm{H}$; H-1), 4.29-4.25 (m, 4H; $\mathrm{H}_{\text {allyl }}$ ), 4.20 (br s, $4 \mathrm{H} ; \mathrm{CH}_{2} \mathrm{~N}$ ), 3.81 (br d, $J=12.2 \mathrm{~Hz}$, $2 \mathrm{H}$; H-6a), 3.65-3.58 (m, 4H; H-6b, H-2), 3.44 (' $\mathrm{t}$ ', $J=9.0 \mathrm{~Hz}, 1 \mathrm{H} ; \mathrm{H}-3), 3.37-\mathrm{s} 3.34$ (m, 4H; H-4, H-5), $1.93 \mathrm{ppm}$ (s, $\left.6 \mathrm{H} ; \mathrm{C}(\mathrm{O}) \mathrm{CH}_{3}\right) ;{ }^{13} \mathrm{C}$ NMR $(150.9 \mathrm{MHz}$, $\left.\mathrm{D}_{2} \mathrm{O}, 20^{\circ} \mathrm{C}\right): \delta=175.4\left(C(\mathrm{O}) \mathrm{CH}_{3}\right), 159.2(\mathrm{OC}(\mathrm{O}) \mathrm{NH})$, $138.6\left(\mathrm{C}_{\mathrm{ar}, \mathrm{q}}\right), 129.7\left(\mathrm{C}_{\text {olefin. }}\right), 129.5\left(\mathrm{C}_{\text {olefin. }}\right), 128.2\left(\mathrm{C}_{\mathrm{ar}}\right)$, 100.7 (C-1), 76.8 (C-5), 74.8 (C-3), 70.7 (C-4), $65.4\left(\mathrm{C}_{\text {allyl }}\right)$, $61.9\left(\mathrm{C}_{\text {allyl }}\right), 61.5(\mathrm{C}-6), 56.4(\mathrm{C}-2), 44.6\left(\mathrm{CH}_{2} \mathrm{~N}\right), 23.0 \mathrm{ppm}$ $\left(\mathrm{C}(\mathrm{O}) \mathrm{CH}_{3}\right.$ ); HRMS (nano ESI, pos. mode, $\mathrm{H}_{2} \mathrm{O} / \mathrm{MeOH}$ ) for $\mathrm{C}_{34} \mathrm{H}_{50} \mathrm{~N}_{4} \mathrm{O}_{16}: \quad[\mathrm{M}+\mathrm{H}]^{+}$calcd 771.3295 ; found: 771.3281, $[\mathrm{M}+\mathrm{Na}]^{+}$calcd 793.3114; found: 793.3115.

4.2.14. $\quad N, N^{\prime}$-Bis-(4-(2-acetamido-2-deoxy- $\beta$-D-glucopyranosyloxy)-( $Z$ )-but-2-enyloxy-carbonyl)- $m$-xylylenediamine (21). According to GP 2, 13 (182 mg, $178 \mu \mathrm{mol})$ was dissolved in $\mathrm{MeOH} / \mathrm{EtMe}_{2} \mathrm{~N}$ 5:1 and reacted for 9 days. 21 was obtained in quantitative yield as a white solid. $R_{\mathrm{f}}=0.51$ $\left(\mathrm{MeCN} / \mathrm{H}_{2} \mathrm{O}\right.$ 4:1); ${ }^{1} \mathrm{H}$ NMR $\left(600.1 \mathrm{MHz}, \mathrm{D}_{2} \mathrm{O}, 20^{\circ} \mathrm{C}\right)$ : $\delta=7.32-7.29\left(\mathrm{~m}, 2 \mathrm{H} ; \mathrm{H}_{\mathrm{ar}}\right), 7.17-7.15\left(\mathrm{~m}, 2 \mathrm{H} ; \mathrm{H}_{\mathrm{ar}}\right), 5.73-$ $5.67\left(\mathrm{~m}, 4 \mathrm{H} ; \mathrm{H}_{\text {vinyl }}\right), 4.56\left(\right.$ br $\left.\mathrm{s}, 4 \mathrm{H} ; \mathrm{H}_{\text {allyl }}\right), 4.46(\mathrm{~d}$, $J=7.6 \mathrm{~Hz}, 2 \mathrm{H} ; \mathrm{H}-1), 4.29-4.24\left(\mathrm{~m}, 4 \mathrm{H} ; \mathrm{H}_{\text {ally }}\right), 4.22$ (br s, $4 \mathrm{H} ; \mathrm{CH}_{2} \mathrm{~N}$ ), 3.81 (br d, $J=12.0 \mathrm{~Hz}, 2 \mathrm{H} ; \mathrm{H}-6 \mathrm{a}$ ), 3.66-3.59 (m, 4H; H-6b, H-2), 3.45 ('t', $J=9.2 \mathrm{~Hz}, 2 \mathrm{H} ; \mathrm{H}-3$ ), 3.383.35 (m, 4H; H-4, H-5), 1.94 ppm (s, $\left.6 \mathrm{H} ; \mathrm{C}(\mathrm{O}) \mathrm{CH}_{3}\right) ;{ }^{13} \mathrm{C}$ NMR $\left(150.9 \mathrm{MHz}, \mathrm{D}_{2} \mathrm{O}, 20^{\circ} \mathrm{C}\right): \delta=175.4\left(C(\mathrm{O}) \mathrm{CH}_{3}\right)$, 159.2 (OC(O)NH), $140.0\left(\mathrm{C}_{\mathrm{ar}, \mathrm{q}}\right), 129.9\left(\mathrm{C}_{\mathrm{ar}}\right), 129.7\left(\mathrm{C}_{\text {olefin }}\right)$, $129.5\left(\mathrm{C}_{\text {olefin. }}\right), 126.9\left(\mathrm{C}_{\mathrm{ar}}\right), 126.3\left(\mathrm{C}_{\mathrm{ar}}\right), 100.8(\mathrm{C}-1), 76.8(\mathrm{C}-$ 5), 74.8 (C-3), $70.7(\mathrm{C}-4), 65.5\left(\mathrm{C}_{\text {ally }}\right), 61.9\left(\mathrm{C}_{\text {ally }}\right), 61.6(\mathrm{C}-$ 6), $56.4(\mathrm{C}-2), 44.8\left(\mathrm{CH}_{2} \mathrm{~N}\right), 23.0 \mathrm{ppm}\left(\mathrm{C}(\mathrm{O}) \mathrm{CH}_{3}\right)$; HRMS (nano ESI, pos. mode, $\mathrm{H}_{2} \mathrm{O} / \mathrm{MeOH}$ ) for $\mathrm{C}_{34} \mathrm{H}_{50} \mathrm{~N}_{4} \mathrm{O}_{16}$ : $[\mathrm{M}+\mathrm{H}]^{+}$calcd 771.3295 , found: $771.3306,[\mathrm{M}+\mathrm{Na}]^{+}$calcd 793.3114; found: 793.3125 .

4.2.15. 1,4-Bis-(3-(4-(2-acetamido-2-deoxy- $\beta$-D-glucopyranosyloxy)-( $Z$ )-but-2-enyloxy-carbonylamino)-propoxy)butane (22). According to GP 2, $14(150 \mathrm{mg}, 137 \mu \mathrm{mol})$ was dissolved in $\mathrm{MeOH} / \mathrm{EtMe}_{2} \mathrm{~N}$ 5:1 and reacted for 5 days. Compound 22 was obtained in quantitative yield as a white solid. $R_{\mathrm{f}}=0.33\left(\mathrm{MeCN} / \mathrm{H}_{2} \mathrm{O} 4: 1\right) ;{ }^{1} \mathrm{H}$ NMR $\left(600.1 \mathrm{MHz}, \quad \mathrm{D}_{2} \mathrm{O}, \quad 20^{\circ} \mathrm{C}\right): \quad \delta=5.73-5.69 \quad(\mathrm{~m}, \quad 4 \mathrm{H}$; $\left.\mathrm{H}_{\text {vinyl }}-\mathrm{H}\right), 4.55$ (br s, $\left.4 \mathrm{H} ; \mathrm{H}_{\text {allyl }}\right), 4.48(\mathrm{~d}, J=8.2 \mathrm{~Hz}$, $2 \mathrm{H} ; \mathrm{H}-1), 4.31-4.28\left(\mathrm{~m}, 4 \mathrm{H} ; \mathrm{H}_{\text {allyl }}\right), 3.85$ (br d, $J=12.1 \mathrm{~Hz}, 2 \mathrm{H}$; H-6a), 3.68 (br d, $J=11.5 \mathrm{~Hz}, 2 \mathrm{H}$; $\mathrm{H}-6 \mathrm{~b}), 3.62$ ('t', 2H; H-2), 3.47-3.45 (m, $10 \mathrm{H} ; \mathrm{CH}_{2}$, $\mathrm{CH}_{2}, \mathrm{H}-3$ ), 3.37 (br s, 4H; H-5, H-4), 3.12 (br s, $4 \mathrm{H}$; $\mathrm{CH}_{2}$ ), 1.97 (s, 6H; $\mathrm{C}(\mathrm{O}) \mathrm{CH}_{3}$ ), 1.69 (br s, $4 \mathrm{H} ; \mathrm{CH}_{2}$ ), $1.55 \mathrm{ppm}$ (br s, $\left.4 \mathrm{H} ; \mathrm{CH}_{2}\right) ;{ }^{13} \mathrm{C}$ NMR $(150.9 \mathrm{MHz}$, $\left.\mathrm{D}_{2} \mathrm{O}, 20^{\circ} \mathrm{C}\right): \delta=175.3\left(C(\mathrm{O}) \mathrm{CH}_{3}\right), 159.1(\mathrm{OC}(\mathrm{O}) \mathrm{NH})$, $129.8\left(\mathrm{C}_{\text {olefin. }}\right), 129.5$ ( $\left.\mathrm{C}_{\text {olefin. }}\right), 100.8(\mathrm{C}-1), 76.8(\mathrm{C}-4$ or C-5), $74.8(\mathrm{C}-3), 71.2\left(\mathrm{CH}_{2}\right), 70.8(\mathrm{C}-5$ or $\mathrm{C}-4), 68.7$ $\left(\mathrm{CH}_{2}\right), 65.5\left(\mathrm{C}_{\text {allyl }}\right), 61.7\left(\mathrm{C}_{\text {allyl }}\right), 61.6(\mathrm{C}-6), 56.4(\mathrm{C}-2)$, $38.5 \quad\left(\mathrm{CH}_{2}\right), \quad 29.7 \quad\left(\mathrm{CH}_{2}\right), \quad 26.2 \quad\left(\mathrm{CH}_{2}\right), \quad 23.0 \mathrm{ppm}$ $\left(\mathrm{C}(\mathrm{O}) \mathrm{CH}_{3}\right) ; \mathrm{HRMS}$ (nano ESI, pos. mode, $\mathrm{H}_{2} \mathrm{O} / \mathrm{MeOH}$ ) for $\mathrm{C}_{36} \mathrm{H}_{62} \mathrm{~N}_{4} \mathrm{O}_{18}$ : $[\mathrm{M}+\mathrm{H}]^{+}$calcd 839.4132; found: 839.4124, $[\mathrm{M}+\mathrm{Na}]^{+}$calcd 861.3951; found: 861.3957.

4.2.16. $\quad N, N^{\prime}$-Bis-(4-(2-acetamido-2-deoxy- $\beta$-D-glucopyranosyloxy)-(Z)-but-2-enyloxycarbonyl)-4,7,10-trioxa-1,13tridecanediamine (23). According to GP 2, 15 (144 mg, $130 \mu \mathrm{mol})$ was dissolved in $\mathrm{MeOH} / \mathrm{EtMe}_{2} \mathrm{~N} \mathrm{5:1}$ and reacted for 5 days. Compound $\mathbf{2 3}$ was obtained in quantitative yield as a white solid. $R_{\mathrm{f}}=0.32\left(\mathrm{MeCN} / \mathrm{H}_{2} \mathrm{O} 4: 1\right)$; ${ }^{1} \mathrm{H}$ NMR $\left(600.1 \mathrm{MHz}, \mathrm{D}_{2} \mathrm{O}, 20{ }^{\circ} \mathrm{C}\right): \delta=5.95-5.92(\mathrm{~m}$, $\left.4 \mathrm{H} ; \mathrm{H}_{\text {vinyl }}\right), 4.78$ (br s, $\left.4 \mathrm{H} ; \mathrm{H}_{\text {allyl }}\right), 4.70(\mathrm{~d}, J=8.4 \mathrm{~Hz}$, $2 \mathrm{H} ; \mathrm{H}-1), \quad 4.54-50 \quad\left(\mathrm{~m}, 4 \mathrm{H} ; \mathrm{H}_{\text {allyl }}\right), 4.07$ (br d, $J=11.9 \mathrm{~Hz}, 2 \mathrm{H}$; H-6a), 3.90 (br d, $J=12.0 \mathrm{~Hz}, 2 \mathrm{H}$; H6b), 3.86-3.82 (m, $\left.10 \mathrm{H} ; \mathrm{CH}_{2}, \mathrm{CH}_{2}, \mathrm{H}-2\right), 3.73$ (br s, 4H; $\mathrm{CH}_{2}$ ), 3.69 (br s, 2H; H-3), 3.60 (br s, 4H; H-4, H5), 3.35 (br s, $\left.4 \mathrm{H} ; \mathrm{CH}_{2}\right), 2.19\left(\mathrm{~s}, 6 \mathrm{H} ; \mathrm{C}(\mathrm{O}) \mathrm{CH}_{3}\right)$, $1.93 \mathrm{ppm} \quad$ ('t', $\left.J=5.8 \mathrm{~Hz}, \quad 4 \mathrm{H} ; \quad \mathrm{CH}_{2}\right) ;{ }^{13} \mathrm{C} \quad \mathrm{NMR}$ $\left(150.9 \mathrm{MHz}, \mathrm{D}_{2} \mathrm{O}, 20^{\circ} \mathrm{C}\right): \delta=175.3\left(C(\mathrm{O}) \mathrm{CH}_{3}\right), 159.1$ $(\mathrm{OC}(\mathrm{O}) \mathrm{NH}), 129.8\left(\mathrm{C}_{\text {olefin }}\right), 129.5\left(\mathrm{C}_{\text {olefin. }}\right), 100.8(\mathrm{C}-1)$, 76.8 (C-5 or C-4), 74.8 (C-3), 70.7 (C-4 or C-5), 70.5 $\left(\mathrm{CH}_{2}\right), 70.2\left(\mathrm{CH}_{2}\right), 69.3\left(\mathrm{CH}_{2}\right), 65.5\left(\mathrm{C}_{\text {allyl }}\right), 61.7\left(\mathrm{C}_{\text {allyl }}\right)$, 61.6 (C-6), 56.4 (C-2), $38.5\left(\mathrm{CH}_{2}\right), 29.6\left(\mathrm{CH}_{2}\right), 23.0 \mathrm{ppm}$ $\left(\mathrm{C}(\mathrm{O}) \mathrm{CH}_{3}\right.$ ); HRMS (nano ESI, pos. mode, $\mathrm{H}_{2} \mathrm{O} / \mathrm{MeOH}$ ) for $\mathrm{C}_{36} \mathrm{H}_{62} \mathrm{~N}_{4} \mathrm{O}_{19}: \quad[\mathrm{M}+\mathrm{H}]^{+}$calcd 855.4081; found: 855.4080, $[\mathrm{M}+\mathrm{Na}]^{+}$calcd 877.3900; found: 877.3907.

4.2.17. 1,7-Bis-(4-(2-acetamido-2-deoxy- $\beta$-D-glucopyranosyloxy)-(Z)-but-2-enyloxycarbonyl)-diethylenetriamine (24). Corresponding to GP 2, 16 (270 mg, $274 \mu \mathrm{mol})$ was dissolved in $\mathrm{MeOH} / \mathrm{EtMe}_{2} \mathrm{~N} \mathrm{5:1}$ and reacted for 4 days. Compound $\mathbf{2 4}$ was obtained in quantitative yield as a slight yellow solid. $R_{\mathrm{f}}=0.08 \quad\left(\mathrm{MeCN} / \mathrm{H}_{2} \mathrm{O} \quad 2: 1\right) ;{ }^{1} \mathrm{H}$ NMR $\left(600.1 \mathrm{MHz}, \mathrm{D}_{2} \mathrm{O}, 20^{\circ} \mathrm{C}\right): \delta=5.72-5.68(\mathrm{~m}, 4 \mathrm{H}$; $\left.\mathrm{H}_{\text {vinyl }}\right), 4.56$ (br s, $\left.4 \mathrm{H} ; \mathrm{H}_{\text {allyl }}\right), 4.47(\mathrm{~d}, J=8.4 \mathrm{~Hz}, 2 \mathrm{H}$; H1), $4.30-4.26\left(\mathrm{~m}, 4 \mathrm{H} ; \mathrm{H}_{\text {allyl }}\right), 3.84$ (br d, $J=12.1 \mathrm{~Hz}, 2 \mathrm{H}$; H-6a), 3.67 (dd, $J=11.1,1.7 \mathrm{~Hz}, 2 \mathrm{H}$; H-6b), 3.61 ('t', $J=$ $=8.1 \mathrm{~Hz}, 2 \mathrm{H} ; \mathrm{H}-2), 3.46$ (br s, $2 \mathrm{H} ; \mathrm{H}-3), 3.37$ (br s, $4 \mathrm{H}$; $\mathrm{H}-4, \mathrm{H}-5$ ), 3.18 (br s, 4H; $\mathrm{CH}_{2}$ ), 2.65 (br s, 4H; $\left.\mathrm{CH}_{2}\right), 1.96 \mathrm{ppm}\left(\mathrm{s}, 6 \mathrm{H} ; \mathrm{C}(\mathrm{O}) \mathrm{CH}_{3}\right) ;{ }^{13} \mathrm{C}$ NMR $(150.9 \mathrm{MHz}$, $\left.\mathrm{D}_{2} \mathrm{O}, 20^{\circ} \mathrm{C}\right): \delta=175.4\left(C(\mathrm{O}) \mathrm{CH}_{3}\right), 159.3(\mathrm{OC}(\mathrm{O}) \mathrm{NH})$, $129.8\left(\mathrm{C}_{\text {olefin. }}\right), 129.5\left(\mathrm{C}_{\text {olefin. }}\right), 100.8(\mathrm{C}-1), 76.8(\mathrm{C}-4), 74.8$ (C-3), $70.8(\mathrm{C}-5), 65.5\left(\mathrm{C}_{\text {allyl }}\right), 61.9\left(\mathrm{C}_{\text {allyl }}\right), 61.6(\mathrm{C}-6), 56.4$ (C-2), 48.3 $\left(\mathrm{CH}_{2}\right), 40.3\left(\mathrm{CH}_{2}\right), 23.0 \mathrm{ppm}\left(\mathrm{C}(\mathrm{O}) \mathrm{CH}_{3}\right)$; HRMS (nano ESI, pos. mode, $\mathrm{H}_{2} \mathrm{O} / \mathrm{MeOH}$ ) for $\mathrm{C}_{30} \mathrm{H}_{51} \mathrm{~N}_{5} \mathrm{O}_{16}$ : $[\mathrm{M}+\mathrm{H}]^{+}$calcd 738.3404; found: 738.3389.

4.2.18. Tris-(2-(4-(2-acetamido-2-deoxy-p-D-glucopyranosyloxy)-(Z)-but-2-enyloxycarbonyl)-aminoethyl)-amine (25). Corresponding to GP 2, 17 (293 mg, $198 \mu \mathrm{mol})$ was dis- 
solved in $\mathrm{MeOH} / \mathrm{EtMe}_{2} \mathrm{~N}$ 5:1 and reacted for 7 days. Compound 25 was obtained as a white solid in quantitative yield. $R_{\mathrm{f}}=0.35\left(\mathrm{MeCN} / \mathrm{H}_{2} \mathrm{O} 2: 1\right) ;{ }^{1} \mathrm{H}$ NMR $\left(600.1 \mathrm{MHz}, \mathrm{D}_{2} \mathrm{O}\right.$, $\left.20^{\circ} \mathrm{C}\right): \delta=5.71-5.70\left(\mathrm{~m}, 6 \mathrm{H} ; \mathrm{H}_{\text {vinyl }}\right), 4.57$ (br s, $6 \mathrm{H} ; \mathrm{H}_{\text {allyl }}$ ), $4.48(\mathrm{~d}, J=8.4 \mathrm{~Hz}, 3 \mathrm{H} ; \mathrm{H}-1), 4.344 .26\left(\mathrm{~m}, 6 \mathrm{H} ; \mathrm{H}_{\text {allyl }}\right), 3.86$ (br d, $J=12.0 \mathrm{~Hz}, 3 \mathrm{H}$; H-6a), 3.69 (br d, $J=11.8 \mathrm{~Hz}, 3 \mathrm{H}$; H-6b), 3.63 ('t', $J=9.3 \mathrm{~Hz}, 3 \mathrm{H} ; \mathrm{H}-2$ ), 3.48 ('t', $J=8.4 \mathrm{~Hz}$, $3 \mathrm{H}$; H-3), 3.40-3.38 (m, 6H; H-4, H-5), 3.15 (br s, 6H; $\left.\mathrm{CH}_{2}\right), 2.60$ (br s, $\left.6 \mathrm{H} ; \mathrm{CH}_{2}\right), 1.98 \mathrm{ppm}\left(\mathrm{s}, 9 \mathrm{H} ; \mathrm{C}(\mathrm{O}) \mathrm{CH}_{3}\right)$; ${ }^{13} \mathrm{C} \quad \mathrm{NMR} \quad\left(150.9 \mathrm{MHz}, \quad \mathrm{D}_{2} \mathrm{O}, \quad 20{ }^{\circ} \mathrm{C}\right): \quad \delta=175.2$ $\left(C(\mathrm{O}) \mathrm{CH}_{3}\right), 159.0(\mathrm{OC}(\mathrm{O}) \mathrm{NH}), 129.6\left(\mathrm{C}_{\text {olefin. }}\right), 100.8(\mathrm{C}-1)$, 76.8 (C-5 or C-4), 74.8 (C-3), 70.7 (C-4 or C-5), $65.5\left(\mathrm{C}_{\text {allyl }}\right)$, $61.8\left(\mathrm{C}_{\text {allyl }}\right), 61.6(\mathrm{C}-6), 56.4(\mathrm{C}-2), 53.5\left(\mathrm{CH}_{2}\right), 38.9\left(\mathrm{CH}_{2}\right)$, $23.1 \mathrm{ppm}\left(\mathrm{C}(\mathrm{O}) \mathrm{CH}_{3}\right)$; HRMS (nano ESI, pos. mode, $\mathrm{H}_{2} \mathrm{O} / \mathrm{MeOH}$ ) for $\mathrm{C}_{45} \mathrm{H}_{75} \mathrm{~N}_{7} \mathrm{O}_{24}:[\mathrm{M}+\mathrm{H}]^{+}$calcd 1098.4936; found: 1098.4938, $[\mathrm{M}+\mathrm{Na}]^{+}$calcd 1120.4736; found: 1120.4803 .

4.2.19. 4-Hydroxy-(Z)-but-2-enyl2-acetamido-2-deoxy- $\beta$ D-glucopyranoside (27). According to GP 2, 4-hydroxy(Z)-but-2-enyl 2-acetamido-3,4,6-tri- $O$-acetyl-2-deoxy$\beta$-D-glucopyranoside $\mathbf{2 6}^{43}(280 \mathrm{mg}, 0.671 \mathrm{mmol})$ was dissolved in $\mathrm{MeOH} / \mathrm{EtMe}_{2} \mathrm{~N}$ 5:1 and reacted for $24 \mathrm{~h}$. Compound 27 was obtained as a white solid in quantitative yield. $R_{\mathrm{f}}=0.38 \quad\left(\mathrm{MeCN} / \mathrm{H}_{2} \mathrm{O} \quad 4: 1\right) ;{ }^{1} \mathrm{H} \quad \mathrm{NMR}$ $\left(400.1 \mathrm{MHz}, \mathrm{D}_{2} \mathrm{O}, 20^{\circ} \mathrm{C}\right): \delta=5.78-5.71\left(\mathrm{~m}, 1 \mathrm{H} ; \mathrm{H}_{\mathrm{vinyl}}\right)$, $5.64-5.53\left(\mathrm{~m}, 1 \mathrm{H} ; \mathrm{H}_{\mathrm{vinyl}}\right), 4.44(\mathrm{~d}, J=8.5 \mathrm{~Hz}, 1 \mathrm{H} ; \mathrm{H}-1)$, 4.28-4.18 (m, 2H; $\left.\mathrm{H}_{\text {allyl }}\right), 4.09-4.07\left(\mathrm{~m}, 2 \mathrm{H} ; \mathrm{H}_{\text {allyl }}\right), 3.83$ (dd, $1 \mathrm{H}, J=12.3,1.2 \mathrm{~Hz}$; H-6b), 3.73-3.63 (m, $1 \mathrm{H} ; \mathrm{H}-$ 6a), 3.59 (dd, $1 \mathrm{H}, J=10.2,8.6 \mathrm{~Hz} ; \mathrm{H}-2), 3.46-3.43$ (m, $1 \mathrm{H} ; \mathrm{H}-5), 3.42-3.38$ (m, 2H; H-3, H-4), $1.95 \mathrm{ppm}(\mathrm{s}$, $\left.3 \mathrm{H} ; \mathrm{C}(\mathrm{O}) \mathrm{CH}_{3}\right) ;{ }^{13} \mathrm{C}$ NMR $\left(100.6 \mathrm{MHz}, \mathrm{D}_{2} \mathrm{O}, 20^{\circ} \mathrm{C}\right)$ : $\delta=174.4\left(C(\mathrm{O}) \mathrm{CH}_{3}\right), 132.7\left(\mathrm{C}_{\text {olefin. }}\right), 126.5\left(\mathrm{C}_{\text {olefin }}\right)$, 99.6 (C-1), 75.7 (C-4 or C-3), 69.7 (C-3 or C-4), 73.7 (C-5), $64.3\left(\mathrm{C}_{\text {allyl }}\right), 60.5$ (C-6), $56.9\left(\mathrm{C}_{\text {allyl }}\right), 55.3(\mathrm{C}-2)$, $21.9 \mathrm{ppm}\left(\mathrm{C}(\mathrm{O}) \mathrm{CH}_{3}\right)$; elemental analysis calcd $(\%)$ for $\mathrm{C}_{12} \mathrm{H}_{21} \mathrm{NO}_{7}$ (291.30): C, 49.48; H, 7.27; N, 4.81; found: C, 49.22; H, 7.44; N, 4.64.

4.2.20. 4-(2-Acetamido-3,4,6-tri- $O$-acetyl-2-deoxy- $\beta$-Dglucopyranosyloxy)-( $Z$ )-but-2-enyloxycarbonyl-(3-(2-(2(3-(trityl-amino)-propoxy)-ethoxy)-ethoxy)propyl)-amine (36). Compound 9 (1.36 g, $2.335 \mathrm{mmol})$ was dissolved in dry $\mathrm{CH}_{2} \mathrm{Cl}_{2}(20 \mathrm{~mL})$. Addition of 3-(2-(2-(3-(trityl-amino)-propoxy)-ethoxy)-ethoxy)-propylamine (900 mg, $1.946 \mathrm{mmol})$ dissolved in $\mathrm{CH}_{2} \mathrm{Cl}_{2}(2 \mathrm{~mL})$ and $\mathrm{EtN}(i-$ $\mathrm{Pr}_{2}(340 \mu \mathrm{L}, 1.946 \mathrm{mmol})$ afforded a yellow colored solution. After stirring overnight at room temperature, removal of the solvent and FC (EtOAc) gave $\mathbf{3 6}$ as a white foam in quantitative yield. $R_{\mathrm{f}}=0.18$ (EtOAc); ${ }^{1} \mathrm{H}$ NMR $\left(600.1 \mathrm{MHz}, \mathrm{CDCl}_{3}, 20{ }^{\circ} \mathrm{C}\right): \delta=7.38-7.36$ $\left(\mathrm{m}, 6 \mathrm{H} ; \mathrm{H}_{\mathrm{ar}}\right), 7.15-7.12\left(\mathrm{~m}, 6 \mathrm{H} ; \mathrm{H}_{\mathrm{ar}}\right), 7.06-7.03(\mathrm{~m}$, $3 \mathrm{H} ; \mathrm{H}_{\mathrm{ar}}$ ), 5.65 (br s, $\left.1 \mathrm{H} ; \mathrm{NH}\right), 5.59$ (br s, $2 \mathrm{H}, \mathrm{H}_{\text {vinyl }}$ ), 5.26 ('t', $J=9.9 \mathrm{~Hz}, 1 \mathrm{H} ; \mathrm{H}-3), 4.98$ ('t', $J=9.6 \mathrm{~Hz}$, $1 \mathrm{H} ; \mathrm{H}-4), 4.75$ (d, $J=7.8 \mathrm{~Hz}, 1 \mathrm{H} ; \mathrm{H}-1), 4.54-4.47$ (m, $\left.2 \mathrm{H} ; \mathrm{H}_{\text {allyl }}\right), 4.29-4.18$ (m, 3H; $\left.\mathrm{H}_{\text {allyl }}, \mathrm{H}-6 \mathrm{a}\right), 4.05$ ('d', $1 \mathrm{H}, J=10.8 \mathrm{~Hz} ; \mathrm{H}-6 \mathrm{~b}), 3.84$ ('q', $J=9.2 \mathrm{~Hz}, 1 \mathrm{H} ; \mathrm{H}-$ 2), $3.72-3.70(\mathrm{~m}, 1 \mathrm{H} ; \mathrm{H}-5), 3.50-3.48\left(\mathrm{~m}, 2 \mathrm{H} ; \mathrm{CH}_{2}\right)$, 3.45-3.43 (m, 6H; $\left.\mathrm{CH}_{2}\right), 3.39-3.38\left(\mathrm{~m}, 4 \mathrm{H} ; \mathrm{CH}_{2}\right), 3.15$ ('d', $J=6.0 \mathrm{~Hz}, 2 \mathrm{H} ; \mathrm{CH}_{2}$ ), 2.14 (br s, $2 \mathrm{H} ; \mathrm{CH}_{2}$ ), 1.95 $\left(\mathrm{s}, 3 \mathrm{H} ; \mathrm{C}(\mathrm{O}) \mathrm{CH}_{3}\right), 1.90\left(\mathrm{~s}, 3 \mathrm{H} ; \mathrm{C}(\mathrm{O}) \mathrm{CH}_{3}\right), 1.89(\mathrm{~s}, 3 \mathrm{H}$; $\left.\mathrm{C}(\mathrm{O}) \mathrm{CH}_{3}\right), 1.83$ (s, 3H; $\left.\mathrm{C}(\mathrm{O}) \mathrm{CH}_{3}\right), 1.66-1.63 \mathrm{ppm}(\mathrm{m}$, $\left.4 \mathrm{H} ; \mathrm{CH}_{2} \mathrm{CH}_{2} \mathrm{CH}_{2}\right) ;{ }^{13} \mathrm{C}$ NMR $\left(150.9 \mathrm{MHz}, \mathrm{CDCl}_{3}\right.$, $\left.20{ }^{\circ} \mathrm{C}\right): \delta=170.8,170.7,170.5,169.5\left(C(\mathrm{O}) \mathrm{CH}_{3}\right), 156.4$ (OC(O)NH), 129.0, 128.7, 128.6, 128.1 127.7, 126.2 $\left(\mathrm{C}_{\mathrm{ar}}, \mathrm{C}_{\mathrm{vinyl}}\right), 99.5$ (C-1), 72.7 (C-3), $71.6(\mathrm{C}-5), 70.9$, 70.5, 70.4, 70.2, 70.0, 69.9, $69.4\left(\mathrm{CH}_{2}\right), 69.0(\mathrm{C}-4), 64.5$ $\left(\mathrm{C}_{\text {allyl }}\right), 62.2(\mathrm{C}-6), 60.3\left(\mathrm{C}_{\text {allyl }}\right), 54.4(\mathrm{C}-2), 41.1,39.03$ $\left(\mathrm{CH}_{2}\right), 30.4\left(\mathrm{CH}_{2} \mathrm{CH}_{2} \mathrm{CH}_{2}\right), 29.4\left(\mathrm{CH}_{2} \mathrm{CH}_{2} \mathrm{CH}_{2}\right), 23.1$, 21.0, 20.9, $20.6 \mathrm{ppm}\left(\mathrm{C}(\mathrm{O}) \mathrm{CH}_{3}\right)$; MALDI-MS (pos. mode, CHCA) for $\mathrm{C}_{48} \mathrm{H}_{63} \mathrm{~N}_{3} \mathrm{O}_{14}:[\mathrm{M}+\mathrm{Na}]^{+}$calcd 928.4; found: $928.5,[\mathrm{M}+\mathrm{K}]^{+}$calcd 944.4; found: 944.4.

4.2.21. 4-(2-Acetamido-3,4,6-tri- $O$-acetyl-2-deoxy- $\beta$-d-glucopyranosyloxy)-(Z)-but-2-enyloxycarbonyl-(3-(2-(2-(3-amino-propoxy)-ethoxy)-ethoxy)propyl)-amine (37). Compound $36(358 \mathrm{mg}, 0.395 \mathrm{mmol})$ was dissolved in dry $\mathrm{CH}_{2} \mathrm{Cl}_{2}$ $(6 \mathrm{~mL})$. Trifluoroacetic acid $(487 \mu \mathrm{L}, 6.32 \mathrm{mmol})$ and triiso-propylsilane $(243 \mu \mathrm{L}, 1.185 \mathrm{mmol})$ were added. After stirring for $1.5 \mathrm{~h}$, the solvent was removed. $\mathrm{FC}\left(\mathrm{CHCl}_{3} /\right.$ $\mathrm{MeOH}$ 6:1) gave 37 in quantitative yield as colorless oil. $R_{\mathrm{f}}=0.06\left(\mathrm{CH}_{2} \mathrm{Cl}_{2} / \mathrm{MeOH} 9: 1\right) ;{ }^{1} \mathrm{H}$ NMR $(600.1 \mathrm{MHz}$, $\mathrm{CDCl}_{3}, 20^{\circ} \mathrm{C}$ ): $\delta=6.89$ (br s, $\left.1 \mathrm{H} ; \mathrm{N} H A \mathrm{Ac}\right), 5.80($ br s, $1 \mathrm{H}$; $\mathrm{NH}$ ), 5.60 (br s, $2 \mathrm{H}, \mathrm{H}_{\text {vinyl }}$ ), 5.19 ('t', $J=9.9 \mathrm{~Hz}, 1 \mathrm{H} ; \mathrm{H}-3$ ), 4.96 ('t', $J=9.0 \mathrm{~Hz}, 1 \mathrm{H} ; \mathrm{H}-4), 4.68(\mathrm{~d}, J=8.4 \mathrm{~Hz}, 1 \mathrm{H} ; \mathrm{H}-$ 1), $4.58-4.50\left(\mathrm{~m}, 2 \mathrm{H} ; \mathrm{H}_{\text {allyl }}\right), 4.32-4.16\left(\mathrm{~m}, 3 \mathrm{H} ; \mathrm{H}_{\text {allyl }}, \mathrm{H}-\right.$ 6a), 4.04 ('d', $J=12.6 \mathrm{~Hz}, 1 \mathrm{H}$; H-6b), 3.93 ('q', $J=9.2 \mathrm{~Hz}$, $1 \mathrm{H} ; \mathrm{H}-2), 3.76$ (br s, $1 \mathrm{H} ; \mathrm{H}-5), 3.55-3.46\left(\mathrm{~m}, 12 \mathrm{H} ; \mathrm{OCH}_{2}\right)$, $3.25-3.18\left(\mathrm{~m}, 2 \mathrm{H} ; \mathrm{CH}_{2} \mathrm{~N}\right), 2.80\left(\right.$ br s, $\left.2 \mathrm{H} ; \mathrm{CH}_{2} \mathrm{~N}\right), 1.99(\mathrm{~s}$, $\left.3 \mathrm{H} ; \mathrm{C}(\mathrm{O}) \mathrm{CH}_{3}\right), 1.93$ (s, 6H; $\left.\mathrm{C}(\mathrm{O}) \mathrm{CH}_{3}\right), 1.85$ (s, 3H; $\mathrm{C}(\mathrm{O}) \mathrm{CH}_{3}$ ), 1.69 ppm (br s, $4 \mathrm{H} ; \mathrm{CH}_{2} \mathrm{CH}_{2} \mathrm{CH}_{2}$ ); ${ }^{13} \mathrm{C}$ NMR $\left(150.9 \mathrm{MHz}, \mathrm{CDCl}_{3}, 20^{\circ} \mathrm{C}\right): \delta=170.7,170.6,170.3,169.4$ $\left(\mathrm{C}(\mathrm{O}) \mathrm{CH}_{3}\right), \quad 156.6(\mathrm{OC}(\mathrm{O}) \mathrm{NH}), 128.7 \quad\left(\mathrm{C}_{\text {olefin }}\right), 128.6$ (C $\mathrm{C}_{\text {olefin. }}$ ), 99.6 (C-1), 72.7 (C-3), 71.6 (C-5), 70.4, 70.3, 70.0, 69.9, 69.6, $69.3\left(\mathrm{OCH}_{2}\right), 68.8(\mathrm{C}-4), 64.6\left(\mathrm{C}_{\text {allyl }}\right), 62.2(\mathrm{C}-6)$, $60.3\left(\mathrm{C}_{\text {allyl }}\right), 54.3(\mathrm{C}-2), 39.6\left(\mathrm{CH}_{2} \mathrm{~N}\right), 38.9\left(\mathrm{CH}_{2} \mathrm{~N}\right), 31.6$ $\left(\mathrm{CH}_{2} \mathrm{CH}_{2} \mathrm{CH}_{2}\right) 29.4 \quad\left(\mathrm{CH}_{2} \mathrm{CH}_{2} \mathrm{CH}_{2}\right), 23.2,23.1,21.0$, 20.9 ppm $\left(\mathrm{C}(\mathrm{O}) \mathrm{CH}_{3}\right)$; HRMS (nano ESI, pos. mode, $\mathrm{H}_{2} \mathrm{O} /$ $\mathrm{MeOH}$ ) for $\mathrm{C}_{29} \mathrm{H}_{49} \mathrm{~N}_{3} \mathrm{O}_{14}:[\mathrm{M}+\mathrm{H}]^{+}$calcd 664.3287; found: 664.3261 .

4.2.22. 4-(2-Acetamido-2-deoxy- $\beta$-d-glucopyranosyloxy)(Z)-but-2-enyloxycarbonyl-(3-(2-(2-(3-amino-propoxy)ethoxy)-ethoxy)propyl)-amine (33). Compound 37 $(259 \mathrm{mg}, 0.39 \mathrm{mmol})$ was dissolved in dry $\mathrm{MeOH}$ $(8 \mathrm{~mL})$. After addition of propylamine $(192 \mu \mathrm{L}$, $2.34 \mathrm{mmol}$ ) and $0.5 \mathrm{M}$ methanolic $\mathrm{NaOMe}$ solution (450 $\mu \mathrm{L}, 225 \mu \mathrm{mol})$ and stirring for $2.5 \mathrm{~h}$, the solvent was evaporated. Compound $\mathbf{3 3}$ was obtained in quantitative yield as colorless oil that was directly used for covalent immobilization. ${ }^{1} \mathrm{H}$ NMR $\left(600.1 \mathrm{MHz}, \mathrm{D}_{2} \mathrm{O}, 20^{\circ} \mathrm{C}\right)$ $\delta=5.70-5.58\left(\mathrm{~m}, 2 \mathrm{H} ; \mathrm{H}_{\text {vinyl }}\right), 4.49-4.48\left(\mathrm{~m}, 2 \mathrm{H} ; \mathrm{H}_{\text {allyl }}\right)$, $4.41(\mathrm{~d}, J=8.4 \mathrm{~Hz}, 1 \mathrm{H} ; \mathrm{H}-1), 4.25-4.21\left(\mathrm{~m}, 2 \mathrm{H} ; \mathrm{H}_{\text {allyl }}\right)$, 3.78 ('d', $J=12.0 \mathrm{~Hz}, 1 \mathrm{H} ; \mathrm{H}-6 \mathrm{a}), 3.62$ (dd, $J=12.0$, $4.8 \mathrm{~Hz}, 1 \mathrm{H} ; \mathrm{H}-6 \mathrm{~b}), 3.57-3.40(\mathrm{~m}, 14 \mathrm{H} ; \mathrm{H}-2, \mathrm{H}-5$, $\left.\mathrm{OCH}_{2}\right), 3.31-3.30$ (m, 2H; H-4, H-5), 3.10-3.05 (m, 2H; $\mathrm{CH}_{2} \mathrm{~N}$ ), 2.64 ('t', $\left.J=6.9 \mathrm{~Hz}, 2 \mathrm{H} ; \mathrm{CH}_{2} \mathrm{~N}\right), 1.90(\mathrm{~s}, 3 \mathrm{H}$; $\left.\mathrm{C}(\mathrm{O}) \mathrm{CH}_{3}\right), 1.65-1.62 \mathrm{ppm}\left(\mathrm{m}, 4 \mathrm{H} ; \mathrm{CH}_{2} \mathrm{CH}_{2} \mathrm{CH}_{2}\right) ;{ }^{13} \mathrm{C}$ NMR $\left(150.9 \mathrm{MHz}, \mathrm{D}_{2} \mathrm{O}, 20^{\circ} \mathrm{C}\right) \delta=175.3\left(C(\mathrm{O}) \mathrm{CH}_{3}\right)$, $159.2(\mathrm{OC}(\mathrm{O}) \mathrm{NH}), 129.9\left(\mathrm{C}_{\text {olefin. }}\right), 129.5\left(\mathrm{C}_{\text {olefin. }}\right), 100.9$ (C-1), 76.9 (C-4 or C-5), 74.9 (C-3), 70.8 (C-5 or C-4), 70.6, 70.3, 69.8, $69.4\left(\mathrm{CH}_{2}\right), 65.5\left(\mathrm{C}_{\text {allyl }}\right), 61.8\left(\mathrm{C}_{\text {allyl }}\right)$, 61.7 (C-6), 56.5 (C-2), 38.7, 38.5, $37.4\left(\mathrm{CH}_{2}\right), 31.3,29.7$ $\left(\mathrm{CH}_{2} \mathrm{CH}_{2} \mathrm{CH}_{2}\right), 23.1 \mathrm{ppm}\left(\mathrm{C}(\mathrm{O}) \mathrm{CH}_{3}\right)$; HRMS (nano ESI, pos. mode, $\left.\mathrm{H}_{2} \mathrm{O} / \mathrm{MeOH}\right)$ for $\mathrm{C}_{23} \mathrm{H}_{43} \mathrm{~N}_{3} \mathrm{O}_{11}$ : $[\mathrm{M}+\mathrm{H}]^{+}$calcd 538.2970; found: 538.2965. 


\subsection{Screening of WGA ligands}

4.3.1. Protocol for non-covalent immobilization of porcine stomach mucin. Microtiter plates (Becton-Dickinson, Falcon ProBind, Cat. No. 353915) were incubated with a solution of porcine stomach mucin (Serva, fraction 5, $\mathrm{pH} 7.0)\left(4.12 \mu \mathrm{g} \mathrm{mL}^{-1}\right)$ in PBS buffer $(10 \mathrm{mM}$ sodium phosphate, $150 \mathrm{mM} \mathrm{NaCl}, \mathrm{pH} 7.3$ ) overnight at room temperature $(100 \mu \mathrm{L}$ per well). The plates were then washed five times with PBST buffer (PBS buffer containing $0.05 \%$ Tween 20 ).

\subsubsection{Protocol for the ELLA employing microtiter plates} with non-covalently immobilized porcine stomach mucin. The coated microtiter plates were blocked with $1 \%$ bovine serum albumin (BSA) in PBS buffer for $90 \mathrm{~min}$ at $37^{\circ} \mathrm{C}(150 \mu \mathrm{L}$ per well). The plates were then washed five times with PBST buffer. Solutions of WGA-HRP (final concentration of $1 \mu \mathrm{g} \mathrm{mL}^{-1}$ ) and any tested inhibitor in serial dilutions in PBS buffer were pre-incubated for $60 \mathrm{~min}$ at $37^{\circ} \mathrm{C}$. Then the WGA-HRP/inhibitor solutions were transferred to the blocked microtiter plates $\left(100 \mu \mathrm{L}\right.$ per well) and incubated at $37^{\circ} \mathrm{C}$ for $90 \mathrm{~min}$. After having washed the plates five times with PBST buffer, a solution of 2,2'-azinobis(3-ethylbenzothiazoline-6-sulfonic acid) diammonium salt (ABTS) $(12.5 \mathrm{mg}$ per $50 \mathrm{~mL})$ in citrate/phosphate buffer (200 mM, pH 4.0) containing $0.015 \%$ of $\mathrm{H}_{2} \mathrm{O}_{2}$ was added $(50 \mu \mathrm{L}$ per well). The plates were incubated for $30 \mathrm{~min}$ at room temperature in the dark. The reaction then was stopped by addition of $1 \mathrm{M} \mathrm{H}_{2} \mathrm{SO}_{4}(50 \mu \mathrm{L}$ per well). After $5 \mathrm{~min}$ in darkness, the absorption was measured at $405 \mathrm{~nm}$ using a plate reader (BMG Labtech, FLUOstar OPTIMA). Percent inhibition was calculated with the following equation:

$$
\begin{aligned}
\% \text { inhibition }= & \left(\left[A_{(\text {no inhibitor })}-A_{(\text {with inhibitor })}\right] / A_{(\text {no inhibitor })}\right) \\
& \times 100
\end{aligned}
$$

$\mathrm{IC}_{50}$ values were reported as the concentration of soluble ligand required for inhibition of $50 \%$ of the binding of WGA-HRP to coated microtiter plates. All tests were performed in duplicate.

4.3.3. Preparation of microtiter plates 32 with aminoreactive isothiocyanate surface. Microtiter plates (Nunc, CovaLink NH modules, Cat. No. 478042) 30 were treated with a $0.5 \%$ solution of 1,4 -phenylene diisothiocyanate $(\mathrm{PDC})$ in $\mathrm{DMSO}^{50,60}$ containing $0.4 \% \mathrm{EtN}(i-\mathrm{Pr})_{2}$ for $3 \mathrm{~h}$ at room temperature $(100 \mu \mathrm{L}$ per well). Then the plates were emptied and rinsed twice with isopropanol, twice with water, and twice with sodium carbonate/ bicarbonate buffer $(100 \mathrm{mM}, \mathrm{pH} 10.1)$ to give modified microtiter plates (32).

4.3.4. Protocol for covalent immobilization of compound 33 to the modified microtiter plates (32). The modified microtiter plates 32 were incubated with a $1 \mathrm{mM}$ solution of compound 33 in sodium carbonate/bicarbonate buffer $(100 \mathrm{mM}, \mathrm{pH} 10.1)$ overnight at room temperature $(100 \mu \mathrm{L}$ per well). The wells were then washed once with isopropanol and twice with PBST buffer $(\mathrm{pH} 7.3)$ to give microtiter plates 34 .
4.3.5. Protocol for the ELLA employing covalently modified microtiter plates (34). This assay was carried out as described above for microtiter plates with noncovalently immobilized porcine stomach mucin except that $100 \mu \mathrm{L}$ per well of each ABTS solution and $\mathrm{H}_{2} \mathrm{SO}_{4}$ were used. All tests were performed in duplicate.

\section{Acknowledgments}

Financial support by the Deutsche Forschungsgemeinschaft (FOR 434 "Oligosaccharide and DNA ChipsAnalysis of Secondary Gene Products") is gratefully acknowledged. We thank Sonja Seeberger for a sample of neoglycopeptide 38 and Reinhold Weber for recording the HRMS spectra.

\section{References and notes}

1. Sharon, N. J. Biol. Chem. 2007, 282, 2753-2764.

2. Gabius, H.-J., Ed.; Animal Lectins. Biochim. Biophys. Acta 2002, 1572, 163-434.

3. Dam, T. K.; Brewer, C. F. Chem. Rev. 2002, 102, 387-429.

4. Lis, H.; Sharon, N. Chem. Rev. 1998, 98, 637-674.

5. Dube, D. H.; Bertozzi, C. R. Nat. Rev. Drug Discov. 2005, 4, 477-488.

6. Gabius, H.-J.; Siebert, H.-C.; André, S.; Jiménez-Barbero, J.; Rüdiger, H. ChemBioChem 2004, 5, 740-764.

7. Shriver, Z.; Raguram, S.; Sasisekharan, R. Nat. Rev. Drug Discov. 2004, 3, 863-873.

8. Essentials of Glycobiology; Varki, A., Cummings, R., Esko, J., Freeze, H., Hart, G., Marth, J., Eds.; Cold Spring Harbor Laboratory Press: Cold Spring Harbor, 1999.

9. Dwek, R. A. Chem. Rev. 1996, 96, 683-720.

10. Werz, D. B.; Seeberger, P. H. Chem. Eur. J. 2005, 11, 3194-3206.

11. Nangia-Makker, P.; Conklin, J.; Hogan, V.; Raz, A. Trends Mol. Med. 2002, 8, 187-192.

12. Rüdiger, H.; Siebert, H.-C.; Solis, D.; Jimenez-Barbero, J.; Romero, A.; von der Lieth, C.-W.; Diaz-Maurino, T.; Gabius, H.-J. Curr. Med. Chem. 2000, 7, 389-416.

13. Gardiner, J. M. Expert Opin. Invest. Drugs 1998, 7, 405-411.

14. Lingwood, C. A. Curr. Opin. Chem. Biol. 1998, 2, 695-700.

15. Lee, Y. C.; Lee, R. T. J. Biomed. Sci. 1996, 3, 221-237.

16. Collins, B. E.; Paulson, J. C. Curr. Opin. Chem. Biol. 2004, 8, 617-625.

17. Mammen, M.; Choi, S.-K.; Whitesides, G. M. Angew. Chem. 1998, 110, 2908-2953; Angew. Chem., Int. Ed. 1998, $37,2755-2794$.

18. Wittmann, V. In Highlights in Bioorganic Chemistry: Methods and Applications; Schmuck, C., Wennemers, H., Eds.; Wiley-VCH: Weinheim, 2004; pp 203-213.

19. Kiessling, L. L.; Pontrello, J. K.; Schuster, M. C.. In Carbohydrate-Based Drug Discovery; Wong, C.-H., Ed.; Wiley-VCH: Weinheim, 2003; Vol. 2, pp 575-608.

20. Roy, R. Trends Glycosci. Glycotechnol. 2003, 15, 291-310.

21. Lindhorst, T. K. Top. Curr. Chem. 2002, 218, 201-235.

22. Houseman, B. T.; Mrksich, M. Top. Curr. Chem. 2002, $218,1-44$.

23. Lee, R. T.; Lee, Y. C. Glycoconjugate J. 2000, 17, 543-551.

24. Lee, Y. C.; Lee, R. T. Acc. Chem. Res. 1995, 28, 321-327.

25. Lundquist, J. J.; Toone, E. J. Chem. Rev. 2002, 102, 555578.

26. Gestwicki, J. E.; Cairo, C. W.; Strong, L. E.; Oetjen, K. A.; Kiessling, L. L. J. Am. Chem. Soc. 2002, 124, 14922-14933. 
27. Kitov, P. I.; Sadowska, J. M.; Mulvery, G.; Armstrong, G. D.; Ling, H.; Pannu, N. S.; Read, R. J.; Bundle, D. R. Nature 2000, 403, 669-672.

28. Fan, E.; Zhang, Z.; Minke, W. E.; Hou, Z.; Verlinde, C. L. M. J.; Hol, W. G. J. J. Am. Chem. Soc. 2000, 122, 26632664.

29. McCoy, J. P., Jr.; Varani, J.; Goldstein, I. J. Anal. Biochem. 1983, 130, 437-444.

30. Rendle, P. M.; Seger, A.; Rodrigues, J.; Oldham, N. J.; Bott, R. R.; Jones, J. B.; Cowan, M. M.; Davis, B. G. J. Am. Chem. Soc. 2004, 126, 4750-4751.

31. Koehn, M.; Benito, J. M.; Mellet, C. O.; Lindhorst, T. K.; Fernandez, J. M. G. ChemBioChem 2004, 5, 771-777.

32. Corbell, J. B.; Lundquist, J. J.; Toone, E. J. Tetrahedron: Asymmetry 2000, 11, 95-111.

33. André, S.; Pieters, R. J.; Vrasidas, I.; Kaltner, H.; Kuwabara, I.; Liu, F.-T.; Liskamp, R. M. J.; Gabius, H.-J. ChemBioChem 2001, 2, 822-830.

34. Roy, R.; Pagé, D.; Figueroa Perez, S.; Verez Bencomo, V. Glycoconjugate J. 1998, 15, 251-263.

35. Haseley, S. R.; Kamerling, J. P.; Vliegenthart, J. F. G. Top. Curr. Chem. 2002, 218, 93-114.

36. Wittmann, V.. In Glycoscience: Chemistry and Chemical Biology; Fraser-Reid, B., Tatsuta, K., Thiem, J., Eds.; Springer-Verlag: Heidelberg, 2001; Vol. III, pp 2253-2287.

37. Nilsson, U.; Striker, R. T.; Hultgren, S. J.; Magnusson, G. Bioorg. Med. Chem. 1996, 4, 1809-1817, In the meantime, microtiter plates with covalently immobilized carbohydrates are also commercially available from Lundonia Biotech (Lund, Sweden). However, no information on the type of linker is given.

38. Wittmann, V.; Seeberger, S. Angew. Chem. 2004, 116, 918921; Angew. Chem., Int. Ed. 2004, 43, 900-903.

39. Wright, C. S. J. Mol. Biol. 1980, 141, 267-291.

40. Wright, C. S.; Kellogg, G. E. Protein Sci. 1996, 5, 1466 1476.

41. Zanini, D.; Roy, R. Bioconjugate Chem. 1997, 8, 187-192.

42. Wittmann, V.; Seeberger, S. Angew. Chem. 2000, 112, 4508-4512; Angew. Chem., Int. Ed. 2000, 39, 4348-4352.
43. Wittmann, V.; Lennartz, D. Eur. J. Org. Chem. 2002, $1363-1367$.

44. de Paz, J. L.; Seeberger, P. H. QSAR Comb. Sci. 2006, 25, 1027-1032.

45. Shin, I.; Park, S.; Lee, M.-r. Chem. Eur. J. 2005, 11, 2894 2901.

46. Feizi, T.; Chai, W. Nat. Rev. Mol. Cell Biol. 2004, 5, 582588.

47. Wang, D. Proteomics 2003, 3, 2167-2175.

48. Feizi, T.; Fazio, F.; Chai, W.; Wong, C.-H. Curr. Opin. Struct. Biol. 2003, 13, 637-645.

49. Ortiz Mellet, C.; Garcia Fernandez, J. M. ChemBioChem 2002, 3, 819-822.

50. Hong, B. J.; Sunkara, V.; Park, J. W. Nucleic Acids Res. 2005, 33, e106.

51. Non-specific binding of WGA to microtiter plates with chemically immobilized GlcNAc employing bifunctional cross-linking reagent divinyl sulfone has been reported earlier: Hatakeyama, T.; Murakami, K.; Miyamoto, Y.; Yamasaki, N. Anal. Biochem. 1996, 237, 188-192.

52. Vrasidas, I.; André, S.; Valentini, P.; Böck, C.; Lensch, M.; Kaltner, H.; Liskamp, R. M. J.; Gabius, H.-J.; Pieters, R. J. Org. Biomol. Chem. 2003, 1, 803-810.

53. Pieters, R. J. Trends Glycosci. Glycotechnol. 2004, 16 , 243-254.

54. Kristiansen, A.; Nysæter, Å.; Grasdalen, H.; Vårum, K. M. Carbohydr. Polym. 1999, 38, 23-32.

55. Bains, G.; Lee, R. T.; Lee, Y. C.; Freire, E. Biochemistry 1992, 31, 12624-12628.

56. Jordan, F.; Bassett, E.; Redwood, W. R. Biochem. Biophys. Res. Commun. 1977, 75, 1015-1021.

57. Nagata, Y.; Burger, M. M. J. Biol. Chem. 1974, 249, 3116 3122 .

58. Privat, J.-P.; Delmotte, F.; Mialonier, G.; Bouchard, P.; Monsigny, M. Eur. J. Biochem. 1974, 47, 5-14.

59. In this experiment the $\mathrm{IC}_{50}$ of GlcNAc was $83 \mathrm{mM}$.

60. Guo, Z.; Guilfoyle, R. A.; Thiel, A. J.; Wang, R.; Smith, L. M. Nucleic Acids Res. 1994, 22, 5456-5465. 